\title{
The physical environment of Kongsfjorden-Krossfjorden, an Arctic fjord system in Svalbard
}

\author{
Harald Svendsen, Agnieszka Beszczynska-Møller, Jon Ove Hagen, \\ Bernard Lefauconnier, Vigdis Tverberg, Sebastian Gerland, \\ Jon Børre Ørbæk, Kai Bischof, Carlo Papucci, \\ Marek Zajaczkowski, Roberto Azzolini, \\ Oddbjørn Bruland, Christian Wiencke, \\ Jan-Gunnar Winther \& Winfried Dallmann

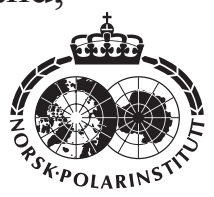

Kongsfjorden-Krossfjorden and the adjacent West Spitsbergen Shelf meet at the common mouth of the two fjord arms. This paper presents our most up-to-date information about the physical environment of this fjord system and identifies important gaps in knowledge. Particular attention is given to the steep physical gradients along the main fjord axis, as well as to seasonal environmental changes. Physical processes on different scales control the large-scale circulation and small-scale (irreversible) mixing of water and its constituents. It is shown that, in addition to the tide, run-off (glacier ablation, snowmelt, summer rainfall and ice calving) and local winds are the main driving forces acting on the upper water masses in the fjord system. The tide is dominated by the semi-diurnal component and the freshwater supply shows a marked seasonal variation pattern and also varies interannually. The wind conditions are characterized by prevailing katabatic winds, which at times are strengthened by the geostrophic wind field over Svalbard. Rotational dynamics have a considerable influence on the circulation patterns within the fjord system and give rise to a strong interaction between the fjord arms. Such dynamics are also the main reason why variations in the shelf water density field, caused by remote forces (tide and coastal winds), propagate as a Kelvin wave into the fjord system. This exchange affects mainly the intermediate and deep water, which is also affected by vertical convection processes driven by cooling of the surface and brine release during ice formation in the inner reaches of the fjord arms. Further aspects covered by this paper include the geological and geomorphological characteristics of the Kongsfjorden area, climate and meteorology, the influence of glaciers, freshwater supply, sea ice conditions, sedimentation processes as well as underwater radiation conditions. The fjord system is assumed to be vulnerable to possible climate changes. and thus is very suitable as a site for the demonstration and investigation of phenomena related to climate change.

H. Svendsen, Geophysical Institute, University of Bergen, Allegt. 70, N-5007 Bergen, Norway; A. Beszczynska-Møller \& M. Zajaczkowski, Institute of Oceanology, Polish Academy of Sciences, 55 Powstancow Warszawy St. 81-712 Sopot, Poland; J. O. Hagen, Dept. of Physical Geography, University of Oslo; B. 
Lefauconnier, French Institute for Polar Research and Technology, Technopole Brest, BP75-29280 Poluzan, France; V. Tverberg, J. B. Ørbcek, J.-G. Winther \& W. Dallmann, Norwegian Polar Institute, Polar Environmental Centre, N-9296 Tromsø, Norway; S. Gerland, Norwegian Polar Institute and (present address) Norwegian Radiation Protection Authority, Polar Environmental Centre, N-9296 Tromsø, Norway; K. Bischof \& C. Wiencke, Alfred Wegener Institute for Polar and Marine Research, Postfach 120161, D-27515 Bremerhaven, Germany; C. Papucci, ENEA, Marine Environment Research Centre, Box 224, 19100 La Spezia, Italy; R. Azzolini, Polarnet - CNR, Institute of Atmospheric Pollution, Monterotondo Scalo 00016, Rome, Italy; O. Bruland, Norwegian University of Science and Technology, N-9491 Trondheim, Norway.

During the last decade various working groups have undertaken great efforts to study the physical environment of KongsfjordenKrossfjorden and the adjacent shelf area (Figs. 1, 2). Interaction between the groups, however, has been modest or totally absent. To rectify this, a multidisciplinary Kongsfjorden Ecosystem Workshop was held at the facilities of the University Courses on Svalbard in Longyearbyen, Svalbard, from 30 October to 5 November 2000. Current information about both the physical environment and the biological ecosystem (Hop et al. 2002 [this issue]) was assembled, discussed and compared to assess the state of our knowledge about the area.

It is believed that in the event of climate change it will most likely be first perceptible in the polar regions due to alterations in ice conditions. To identify such changes it is appropriate to choose the most vulnerable sites, consolidate the state of our knowledge for the sites and develop a plan for sampling of time series of selected parameters. The Kongsfjorden-Krossfjorden system is in this respect a very suitable site. Climate change will most likely influence the fjord system from two directions - the ends opening out into the sea and the inner ends abutting the glaciersrendering the fjord system a sensitive indicator of climate change phenomena. Alteration of melting of the glaciers will change the run-off pattern, and temperature and/or salinity changes in the adjacent Atlantic and Arctic water will cause changes in the fjords through exchange processes.

The main objective with this paper is to give an overview of the most current knowledge of the physical, non-biological conditions in the gradient from the glaciers at the head of Kongsfjorden, along the fjord and across the shelf, including the shelf slope. It is hoped that this will serve as a basis for future research, filling current gaps in our knowledge. Special focus is given

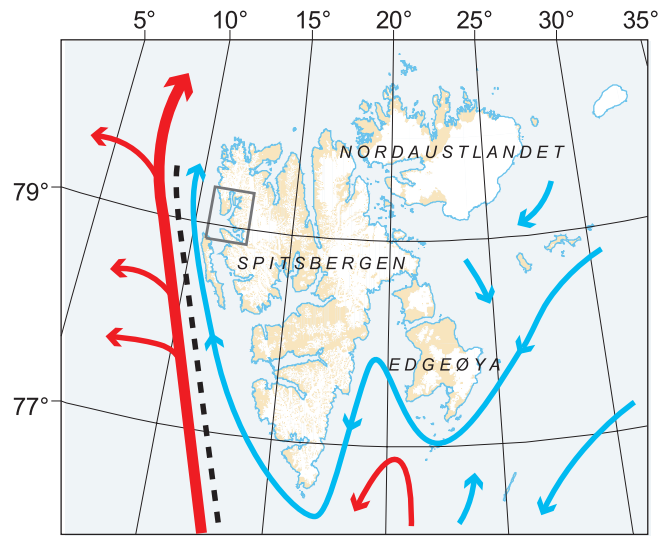

Fig. 1. Map of Svalbard showing the major currents. Off the coast of western Spitsbergen is the West Spitsbergen Current (thick red) and the Arctic-type coastal water (blue). The dashed black line indicates the frontal area between the two currents.

to circulation and exchange processes. It is also hoped that the paper proves useful for biologists requiring information on the abiotic environment for interpretation of their data. While the paper is predominantly concerned with Kongsfjorden, where most of the knowledge has been assembled, the section on physical oceanographic processes also incorporates data from Krossfjorden.

Oceanographic conditions in the western Spitsbergen fjords are strongly related to the characteristics of the currents flowing around the Svalbard Archipelago (Fig. 1). Great amounts of heat (between 35 and 70 TW; P. M. Haugan, pers. comm.) and salt are transported into the Arctic Ocean by the West Spitsbergen Current (WSC), the northernmost extension of the Norwegian Atlantic Current. Warm and saline Atlantic Water (AW) occupies the upper ca. $600 \mathrm{~m}$ of the WSC branch, which follows the continental slope of west Spitsbergen northward. The area west of the shelf is therefore essentially ice-free (Aagaard 


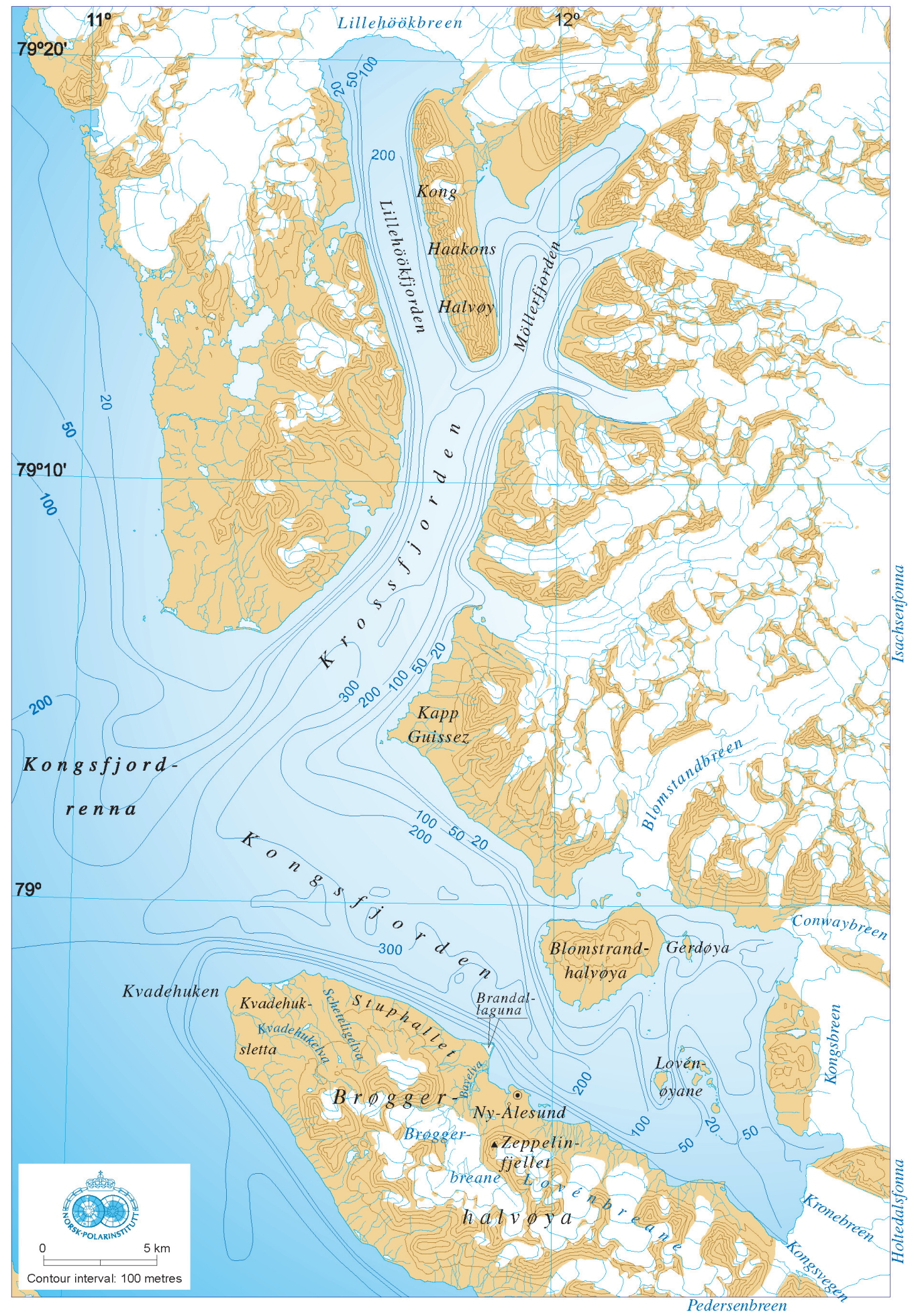

Fig. 2. Map of Kongsfjorden-Krossfjorden. 
et al. 1987; Gascard et al. 1995). In recent years the Arctic ice extent has diminished (Vinje 2001) and the temperature of the AW in the WSC has increased; these changes are apparently linked to changes in the atmospheric circulation towards north-western Europe, which are related to an increased North Atlantic Oscillation index. On the shelf, cold and relatively fresh Arctic Water (ArW) flows northward in a coastal current. The current flows from Storfjorden, and rounds the southern tip of Spitsbergen (Fig. 1).

The Kongsfjorden-Krossfjorden system and the shelf meet at the common mouth of the two fjords. Rather than a sill in the mouth, there is a prominent trench of decreasing depth towards the shallow shelf. Exchanges in this active shelffjord boundary have a decisive impact on both the hydrophysical and biological variability in the fjord system. The exchanges replace intermediate and deep fjord water with ArW and AW. At present, the temporal and spatial scales of the flux exchange are not known. The exchange varies on time scales of days, weeks or longer and is controlled by the geostrophic coastal flow regimes, as suggested by Klinck et al. (1981).

Kongsfjorden-Krossfjorden is a glacial fjord system, which has some characteristics specific to Arctic fjords and others which it shares with other broad fjords. Features common to broad fjords relate to the freshwater supply and water temperature, which have a seasonal pattern, dominating wind directions (down-fjord in the winter season and up-fjord in summer with orographic precipitation), and the corresponding impact on the stratification and circulation, which varies considerably during the year, (see e.g. Pickard 1961; Gade 1970; Svendsen 1981; Farmer \& Freeland 1983). Another shared feature relates to the rotational dynamics (Coriolis effect), which have been shown to have an important impact on fjord dynamics in wide and stratified fjords such as Kongsfjorden-Krossfjorden (Proehl \& Rattray 1984; Cushman-Roisin et al. 1994; Asplin 1995; Svendsen 1995; Asplin et al. 1999).

The specifically Arctic features of the fjord system are primarily related to the way the freshwater is supplied to the fjords. Freshwater is supplied as meltwater from the surface and at deeper levels as icebergs from calving glaciers. The latter implies that the fjords are influenced by freshwater throughout the year, although only to a slight degree in the long winter season.
The influence on the estuarine circulation and mixing processes from an active glacier system is significant (Matthews \& Quinlan 1975; Matthews 1981). Freezing and melting of fast ice, which take place in the inner part of the fjord arms, have a two-fold effect on the fjord dynamics: removal and supply of freshwater from the surface layer during freezing and melting, respectively; and the homogenization of the water masses due to vertical convection initiated by salt rejection during freezing.

\section{Geology and geomorphology}

The system formed by Kongsfjorden and Krossfjorden is located between $78^{\circ} 40^{\prime}$ and $77^{\circ} 30^{\prime} \mathrm{N}$ and $11^{\circ} 3^{\prime}$ and $13^{\circ} 6^{\prime} \mathrm{E}$. Kongsfjorden is oriented from south-east to north-west and Krossfjorden from north to south. The fjords consist of two submarine channels, which converge to a deep glacial basin, the Kongsfjordrenna. The total area of both drainage basins is $3074 \mathrm{~km}^{2}$, a land area of $2257 \mathrm{~km}^{2}$ with $1651 \mathrm{~km}^{2}$ or $74 \%$ covered by glaciers and a marine area of $817 \mathrm{~km}^{2}$ (Table 1).

Kongsfjorden is $20 \mathrm{~km}$ long, its width varying from 4 to $10 \mathrm{~km}$ reached at the mouth between Kvadehuken and Kapp Guissez. There is a wellmarked inner fjord with relatively shallow water less than $100 \mathrm{~m}$ deep (zone 4 and a large part of zone 3 in Fig. $1 b$ in Hop et al. 2002) and a deeper fjord (zones 2 and 3, in Fig. 1b in Hop et al. 2002). The total volume of Kongsfjorden is estimated as $29.4 \mathrm{~km}^{3}$ (Ito \& Kudoh 1997).

Krossfjorden is about $30 \mathrm{~km}$ long. Its width varies between 3 and $6 \mathrm{~km}$. Kong Haakons Halvøya (King Haakon Peninsula) divides the inner part of the fjord into two parts, Lilliehöökfjorden and Möllerfjorden. The volume of Krossfjorden is estimated to about $25 \mathrm{~km}^{3}$.

Both Kongsfjorden and Krossfjorden are strongly influenced by the presence of tidewater glaciers: Lilliehöökbreen at the head of Krossfjorden (Lilliehöökfjorden), five other calving glaciers along its eastern coast; Kronebreen and Kongsvegen at the head of Kongsfjorden, and Conwaybreen and Blomstrandbreen on its northern coast.

\section{Geology}

Kongsfjorden is situated on a major tectonic boundary between the Tertiary fold-thrust belt 
of western Spitsbergen to the south-west and the Northwestern Basement Province of Svalbard to the north-east (Bergh et al. 2000). The glacier Kongsvegen, and its deglaciated prolongation, Kongsfjorden, have probably been formed in a morphological depression caused by strong fracturing of the bedrock in a zone paralleling the thrust front.

The bedrock north of Kongsfjorden and on the islands in the fjord consists of mediumgrade metamorphic rocks of most probably Middle Proterozoic age, mainly marbles, micaschists, and minor amounts of quartzites. In a north-south trending zone comprising the island known as Blomstrandhalvøya and the islands named Lovénøyane, slices of unmetamorphosed rocks of Devonian age - red conglomerates and sandstones - are tectonically interlayered with marbles. South of Kongsfjorden, on Brøggerhalvøya (Brøgger Peninsula), structurally above the basal Tertiary thrust, sedimentary rocks of Late Palaeozoic and-locally-Tertiary Age prevail, although some Proterozoic, lowand medium-grade metamorphic rocks (micaschists, marbles, phyllites, quartzites) occur in a few thrust sheets in the south-eastern part of Brøggerhalvøya. Late Palaeozoic rocks comprise conglomerates, sandstones, carbonate rocks of both calcitic and dolomitic composition, as well as spiculitic rocks (cherts, siliceous limestones). Tertiary rocks occur only in two thrust sheets in the vicinity of Ny-Ålesund. They are conglomerates, sandstones and shales with numerous interbedded coal seams. An approximate total of 1.43 million tonnes of coal was exported from Ny-Ålesund between 1917 and 1962 (Hjelle et al. 1999).

\section{Geomorphology}

Landforms around Kongsfjorden are shaped by glacial activity. The extent of the last glaciation is still being discussed but Brøggerhalvøya and the areas to the north were probably completely ice-covered prior to $13600 \mathrm{BP}$. The Kongsfjorden area shows a more complete glacial sedimentary record-back to ages older than Eemian (the last interglacial) - than most other places in Svalbard. Sections on Brøggerhalvøya show four isostatically induced cycles of emergence during the Weichselian glaciation (Miller et al. 1989).

By 9500 BP, all glaciers had started to retreat. It is likely that the area was completely ice- free during a long period until the "neoglacial" advance. This started at an unknown date and is thought to be not older than $4500 \mathrm{BP}$, but could be younger. The maximum ice extent during the Holocene occurred during the Little Ice Age. Large ice-cored moraines in front of the glaciers in the inner part of Kongsfjorden derive from the youngest ice advances in the 1800s, although they contain redeposited, much older material from a glacial stage with a smaller extent (Hjelle et al. 1999). As is the case for Kongsbreen, the maximum extent of glaciers may result from surge dynamics.

On Brøggerhalvøya, Kvadehuksletta shows splendid exposures of post-glacial beach ridges up to the marine limit at $80 \mathrm{~m}$. These provide information on the uplift history of the last 290000 years; only ridges below 44 m elevation are derived from the post-glacial period (ca. 12000 years ago) (Forman \& Miller 1984).

The area is characterized by a contrast between the alpine relief and coastal platforms. Active glacial, hydro-glacial, periglacial and coastal processes influence the landscape. In front of terrestial glaciers streams rework the moraine deposits. The rivers form braided drainage systems that create wide sandurs with a number of small channels that are seasonally active, and with coarse fluvial deposits and limited vegetation. Three rivers-Scheteligelva, Kvadehukelva and Bayelva-have cut permanent valleys. Large deltas are built up at the mouths of the rivers. An example on Kongsfjorden's southern coast, the delta closest to the front of Kongsvegen was almost completely formed between 1975 and 1983. In those eight years, the delta built out nearly $180 \mathrm{~m}$. Its volume is estimated to be about $4.5 \times 10^{6} \mathrm{~m}^{3}$ (Lefauconnier 1987). The main sedimentation source is from the subglacial meltwater discharge from the tidewater glaciers. The amount of sediments discharged over a summer at the front of Kronebreen-Kongsvegen was estimated to be about $0.25 \times 10^{6} \mathrm{~m}^{3}$ (Elverhøi et al. 1980), and the corresponding erosion rate over the same period was between 0.3 and 0.6 $\mathrm{mm}$ over a basin of $800 \mathrm{~km}^{2}$. Rates of silt/clay sedimentation (unconsolidated sediments) at the ice front are $>10 \mathrm{~cm} \mathrm{a}^{-1}$. Elverhøi et al. (1980) estimated that these sediments could fill the inner fjord in 500 years.

Permafrost is continuous in Svalbard, with depths varying between 200 and $450 \mathrm{~m}$ in the interior. In Kongsfjorden, permafrost has been 

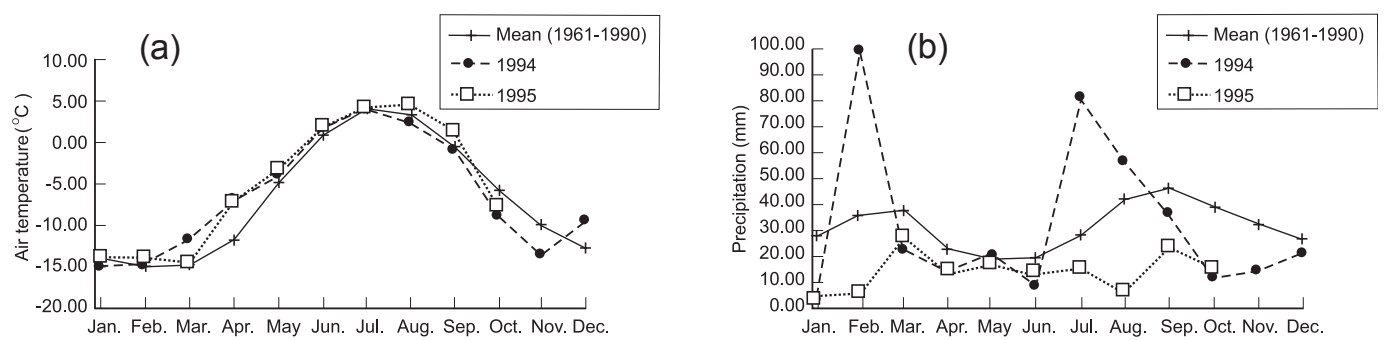

Fig. 3. Monthly mean values of (a) air temperature and (b) precipitation in Ny-Ålesund, 1994 and 1995.

measured down to $140 \mathrm{~m}$ in a borehole in front of Brøggerbreen (Brøgger Glacier) (Liestøl 1976, 1980). Periglacial processes on the slopes generate talus deposits at the transition between slopes and coastal platforms. Some of these form pro-talus ramparts and rock glaciers, e.g. at the foot of Zeppelinfjellet (Zeppelin Mountain) and at Stuphallet (Stup Cliff) on Brøggerhalvøya, and in the northern part of Blomstrandhalvøya. The rock glaciers move very slowly $\left(3-4 \mathrm{~cm} \mathrm{a}^{-1}\right.$ or less; Sollid \& Sørbel 1992). Patterned ground and sorted circles are well developed in the lowland areas of Brøggerhalvøya, especially on the coastal platform of Kvadehuken. Lagoons (e.g. Brandallaguna) and single bars are found along all the coasts, especially on the emerged strandflats.

Dissolution of bedrock in limestone areas has in places resulted in a landscape with karst features. Most of these are small-scale surface features, but some larger features also occur, e.g. on Blomstrandhalvøya, where small caves can be observed (Blümel 1971).

\section{Climate and meteorology}

\section{General characteristics}

The climate of Svalbard is strongly influenced by the atmospheric general circulation, the annual variation in light conditions, Arctic sea ice extent and ocean currents. The large-scale circulation is governed by the Icelandic Low and the high pressures over Greenland and the Arctic Ocean, which force warm and humid air from the North Atlantic Ocean along the cyclone tracks to the Norwegian and Barents seas. The large difference in temperature between air masses of Arctic or Atlantic origin cause great fluctuations in weather conditions, especially during winter (Hansen-Bauer et al. 1990; Førland et al. 1997). The WSC causes ice-free conditions along the western coast throughout the year and partially ice-free waters north of Svalbard even during winter (Vinje 1982).

In Kongsfjorden, as elsewhere in Svalbard, the number of overcast days and the frequency of Arctic sea fog formed by the advection of mild maritime air over colder surfaces, is highest during summer, especially along the coast. The number of clear days in Ny-Ålesund is highest (5- 8 days/month) during the winter months and lowest (only 1 day/month) during the summer (June to September), with a sharp transition occurring from May to June (Førland et al. 1997). Typical seasonal temperature and precipitation distributions for the Ny-Ålesund area are shown in Fig. 3. Hansen-Bauer et al. (1990) found that the winter temperatures show relatively high values and large fluctuations similar to the more central part of the island (e.g. Longyearbyen), whereas the summer temperatures are more representative of the coastal stations. They concluded that NyÅlesund has a more continental climate during the winters and a coastal climate during the summers because Kongsfjorden is frozen during

Table 1. Area of the drainage basins to Krossfjorden and Kongsfjorden and volume of the glaciers.

\begin{tabular}{lcccccc}
\hline & $\begin{array}{l}\text { Basin } \\
\left(\mathrm{km}^{2}\right)\end{array}$ & $\begin{array}{c}\text { Land } \\
\left(\mathrm{km}^{2}\right)\end{array}$ & $\begin{array}{c}\text { Glaciers } \\
\left(\mathrm{km}^{2}\right)\end{array}$ & $\begin{array}{c}\text { Glaciers } \\
\left(\mathrm{km}^{3}\right)\end{array}$ & $\begin{array}{c}\text { Ice-free } \\
\left(\mathrm{km}^{2}\right)\end{array}$ & $\begin{array}{c}\text { Sea } \\
\left(\mathrm{km}^{2}\right)\end{array}$ \\
\hline Kongsfj. & 1428 & $\begin{array}{c}1100 \\
(77 \%)\end{array}$ & 214 & 329 & \\
Krossfj. & 829 & 551 & $\begin{array}{c}94 \\
(67 \%)\end{array}$ & 278 & & \\
Total & 3074 & 2257 & $\begin{array}{c}1651 \\
(74 \%)\end{array}$ & 308 & 607 & 817 \\
& & & & & \\
\hline
\end{tabular}


winter, but open and strongly influenced by the ocean during the summer. A recent study of a 17-year (1981-1997) record of surface albedo in Ny-Ålesund suggests that the snow-free season typically lasts 94 days (Winther et al. 2002).

\section{Wind patterns}

The most common wind direction on Spitsbergen is always along valleys or fjords from inland to the sea, and the prevailing winds are from the north-east to the south-east sectors, except during summer (Hansen-Bauer et al. 1990; Førland et al. 1997). The wind conditions in Kongsfjorden are to a large extent governed by orographic steering of the large-scale wind fields and katabatic winds transporting cold dense air from the inland glaciers to the warmer fjords. Prevailing winds at Ny-Ålesund flow from the south-east $\left(120^{\circ}\right.$, from the head of the fjord toward its mouth), with a second mode from north-west $\left(310-330^{\circ}\right.$, into the fjord). This is confirmed by the ARTIST (Arctic Radiation and Turbulence Interaction Study) scatter plots of the wind speed against wind direction which are assembled based on the sodar for $65 \mathrm{~m}$ and $224 \mathrm{~m}$ altitude, respectively (Argentini et al. 2000) (Fig. 4).

Hartmann et al. (1999) used sodar and other ground-based instruments to characterize the boundary layer of the Kongsfjorden area. They confirmed that the observed predominant atmospheric conditions involved spiky structures (gusts/highly variable winds) and waves. The spiky structures were observed during forced convection when the atmospheric stratum experienced continued strong wind shear in katabatic flow. Spiky structures prevailed in the first part of the field experiment, coincident with strong synoptic south-easterly winds. Internal gravity waves, on the other hand, were produced by gentle dynamic instabilities in the statically stable layer. These two features generally alternated depending on the local wind field, cloud cover, sunshine and geostrophic circulation (Argentini et al. 2000).

The direction and speed at 1200 LST of the geostrophic and low level winds are plotted as a function of time in Fig. 5 (from Argentini et al. 2000). A difference between the two wind regimes of about $30^{\circ}-40^{\circ}$ is observed from 24-30 March, when the wind speed at both levels is about $10-14 \mathrm{~m} \mathrm{~s}^{-1}$. In this case the geostrophic wind enhances the katabatic flow. Between 6

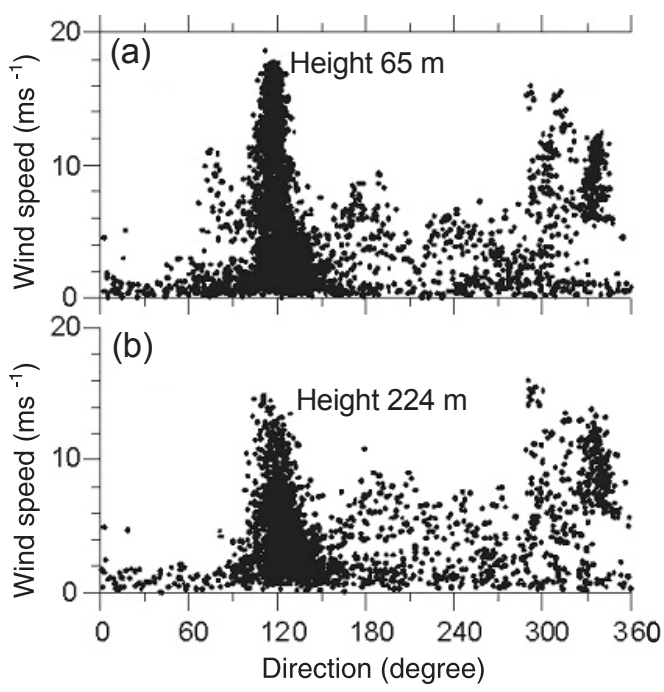

Fig. 4. Scatter plot of the wind speed versus the wind direction during ARTIST (Arctic Radiation and Turbulence Interaction Study) given by the sodar for (a) $65 \mathrm{~m}$ and (b) $214 \mathrm{~m}$ altitude. (from Argentini et al. 2000; printed with permission of the author and the Societa' Italiana di Fisica; copyright Societa' Italiana di Fisica))

and 12 April, the geostrophic wind rotates to the northern sector with a decline in wind intensity, although low level winds still persist from the east-south-east. A large deviation $\left(50^{\circ}-180^{\circ}\right)$ is observed between the two flows; in this case the geostrophic wind does not influence the flow from Kongsvegen, which is simply gravity driven down the slope of the glacier. This large difference in the wind direction between the surface and geostrophic flows is determined by the position of the high-low pressure system over Svalbard, which causes a coupling of the low level and geostrophic circulation when the low pressure centre is located south-west of Svalbard and a decoupling when the centre is farther north.

Wind conditions in the inner part of Kongsfjorden have been measured by Gerland et al. (unpubl. data) with an automatic weather station installed on Gerdøya from February to August 1998. The measurements showed reasonable agreement with the general wind pattern observed in Ny-Ålesund, and wind speeds above $12 \mathrm{~m} \mathrm{~s}^{-1}$ (gusts) were registered in midFebruary and during the second half of March, with prevailing winds from the south-east $\left(120^{\circ}\right)$. These winds were accompanied by an increase in air temperature, occasionally reaching values 


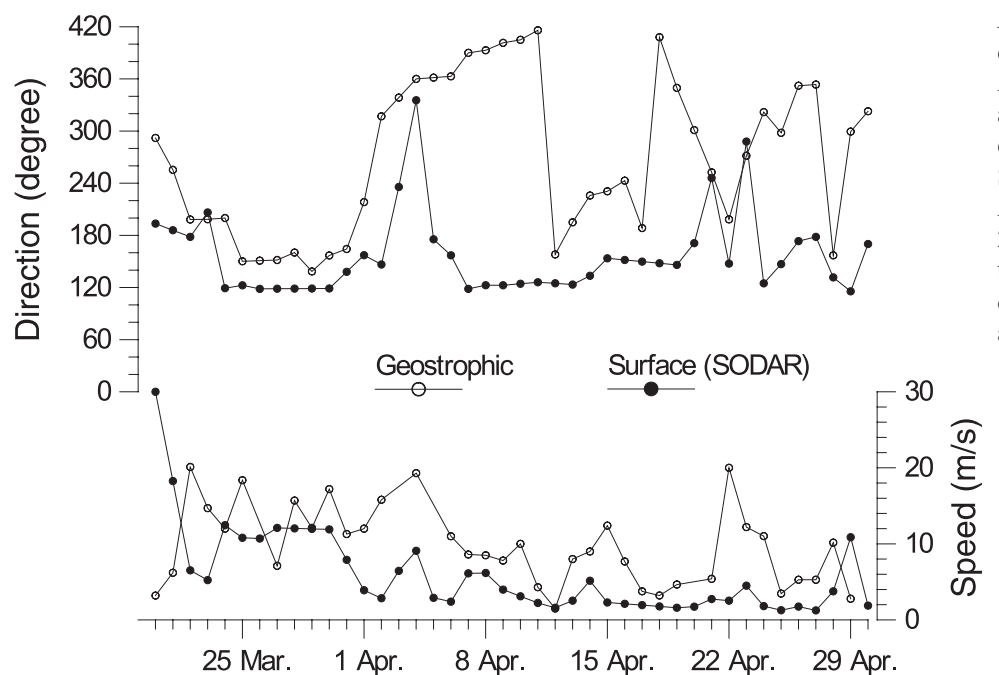

Fig. 5. Time series of the wind direction and speed from $\mathrm{Ny}$ Ålesund given by sodar at $65 \mathrm{~m}$ altitude and the geostrophic wind during ARTIST at 1200 Local Standard Time, 20 March - 30 April 1998 (from Argentini et al. 2000; printed with permission of the author and the Societa' Italiana di Fisica; copyright Societa' Italiana di Fisica).

above $0{ }^{\circ} \mathrm{C}$ in the second half of March. Other prominent wind directions were registered from the north-west $\left(290^{\circ}, 310^{\circ}\right)$ with increased wind speed for shorter times. This mode is likely to be controlled by the hills of Blomstrandhalvøya, less than $1 \mathrm{~km}$ west of Gerdøya.

\section{Radiation conditions}

The radiation regime in Ny-Ålesund is influenced by the open ocean climate to the west (and south) of Svalbard during summer and autumn, with Arctic sea fog and low albedo playing a key role (Ørbæk et al. 1999). During late winter and spring, the radiation regime is more of a continental type, similar to the central mainland climate, due to the frozen fjords, drifting sea ice and seasonal snow cover. There are significant differences between these two radiation regimes induced by the large annual variation of surface albedo (land-ocean) and sea ice cover, as well as the ocean-related Arctic fog conditions during summer. The heterogeneous surfaces found in the Ny-Ålesund area (partly ice-covered fjord, vegetated tundra and glaciers) induce local variations in the radiation regime, especially during the melting season in spring.

The radiation climate of Kongsfjorden is marked by pronounced seasonal variations. The sun stays below the horizon from 25 October to 17 February, the polar day lasts from 18 April to 23 August, and twilight conditions prevail during spring and autumn. Solar radiation is highly variable during the summer season and is influenced by a number of atmospheric factors such as the weather conditions (clouds and fog), aerosols in the atmosphere and stratospheric ozone (affecting the UV-B intensity). The annual maximum of atmospheric sunshine duration (SSD) is $4474.6 \mathrm{~h} \mathrm{a}^{-1}$ (data derived from the Baseline Surface Radiation Network station in Ny-Ålesund; see König-Langlo \& Marx 1997). On an annual basis for the period 19962000, the mean SSD at ground level was about $933.3 \mathrm{~h} \mathrm{a}^{-1}$, with a maximum in $1997\left(1327.0 \mathrm{~h} \mathrm{a}^{-1}\right)$ and minimum in $1998\left(722.1 \mathrm{~h} \mathrm{a}^{-1}\right)$.

In the period 1996-98, the mean yearly flux of visible radiation (370-695 nm), was 1042.6 MJ m². Daily mean measurements of visible radiation, calculated from 1 March to 31 October exhibited maximum values of $54.3 \mathrm{~W} \mathrm{~m}^{-2}$ in 1998 (see Hanelt et al. 2001). Maximum irradiances were always recorded during June and July (Fig. 6). Under sunny conditions, irradiances of photosynthetically active radiation (PAR, 400-700 $\mathrm{nm}$ ) can increase to $1300 \mu \mathrm{mol} \mathrm{m}^{-2} \mathrm{~s}^{-1}$ (Bischof et al. 1998). During this time, maximum daily mean of visible radiation $(370-695 \mathrm{~nm})$ up to $170 \mathrm{~W} \mathrm{~m}^{-2}$ can be measured. In parallel, a daily irradiance of UV radiation $(300-370 \mathrm{~nm})$ of about $16.8 \mathrm{~W} \mathrm{~m}^{-2}$ has been detected (Hanelt et al. 2001).

Sensitive UV-A and UV-B spectroradiometers have shown that maximum daily doses of UVA radiation $(320-400 \mathrm{~nm})$ in Ny-Ålesund can reach up to about $1600 \mathrm{~kJ} \mathrm{~m}^{-2}$, with maximum irradiance levels at about $19 \mathrm{~W} \mathrm{~m}^{-2}$ (Bischof et al. 
Fig. 6. Daily averaged solar irradiance in Ny-Ålesund: circles represent mean values of visible radiation (1996-99; 370 - $695 \mathrm{~nm}$ ); lines show minimal and maximal values of visible radiation, illustrating daily variations; triangles are mean values of $U V-B$ radiation (1998-2000; $280-320 \mathrm{~nm})$. Data from the Baseline Surface Radiation Network station.

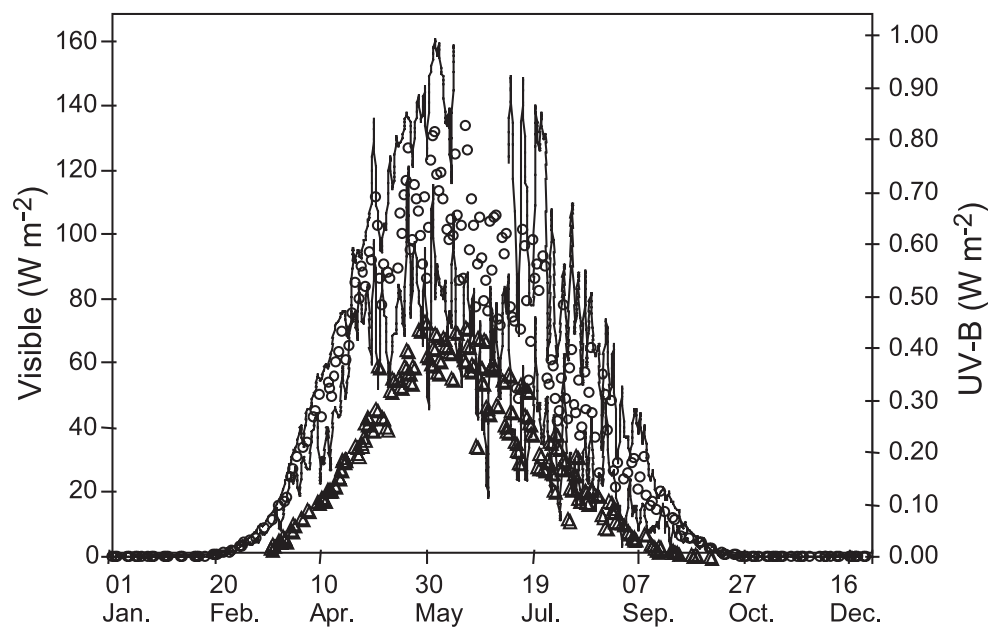

tion and heat budget.

\section{Glaciers and freshwater supply}

Data about the drainage basins feeding Kongsfjorden and Krossfjorden and the areas covered by glaciers are shown in Table 1 . The main glacierized area consists of the large glacier complex in the inner part of the fjords, with several calving fronts at the head of the fjords. These glaciers drain the large icefields of Isachsenfonna and Holtedalfonna. On the northern side of Kongsfjorden, Blomstrandbreen also has a calving front. On the southern side there are several valley or cirque glaciers. None of them reach the fjord.

\section{Temperature regime}

The temperature conditions in the glaciers are of great importance for their flow and the hydrology. Like most of Svalbard's glaciers, glaciers in the Kongsfjorden basin are subpolar or polythermal, which means that parts are temperate (above or close to zero) where meltwater can be present and parts are cold (below zero). In the accumulation area during the melting period, water percolates down into the snow and firn layers. Due to the negative temperature in these layers, the water refreezes, releasing latent heat and raising the temperature to the melting point early in the melt season. In the accumulation area, the deep firn and ice layers remain at the pressure melting point throughout the year, resulting in 
an unfrozen sub-glacial talik in the permafrost under the central, thickest part of the glaciers. Thus, water can penetrate to the bed of the glacier and feed the groundwater below the permafrost. In the ablation area, meltwater drains across the ice surface into either ice-marginal channels or moulins. No refreezing occurs within the ice and, as the annual mean atmospheric temperature is negative (Fig. 3), the ice temperature stays below zero. In glaciers ending on land, the temperate layer does not reach the ice front where there is continuous permafrost. Calving glaciers influenced by the temperature of the sea have partly or completely temperate tidewater tongues. The thermal regime has been confirmed by measurements in boreholes drilled to bedrock and by the interpretation of radar echo-soundings carried out from the glacier surface (Björnsson et al. 1996).

The water in the temperate layers also drains during winter. In front of glaciers ending on land, this winter discharge refreezes and builds up "naled ice" (icing). Since all the glaciers in Svalbard are either cold or polythermal (subpolar), the presence of naled ice strongly suggests that the glacier is a sub-polar glacier. At the front of tidewater glaciers the winter run-off is released directly into the fjord.

\section{Mass balances}

Glaciers contribute to the freshwater supply to the fjord by melting and calving. Glacier melting is best estimated by measurements of summer mass balance. The net balance (bn) is the sum of accumulation (bw) and ablation (bs), and gives the gain or loss of ice over one year. Snow accumulation may also occur in the higher parts of the glaciers during summer, while melting occurs in the lower parts. The summer balance measures the transfer of water during one year (one summer).

Glacier mass balance measurements have been carried out continually since 1967 on two small glaciers, Austre Brøggerbreen and Midre Lovénbreen (both ca. $5 \mathrm{~km}^{2}$ ), and since 1987 on Kongsvegen $\left(100 \mathrm{~km}^{2}\right)$ (Hagen \& Liestøl 1990; Lefauconnier et al. 1999) (Table 2, Fig. 7). The net balance of Brøggerbreen and Lovénbreen has generally been negative during the nearly 30 years of observations, with mean net balances of $-0.45 \mathrm{~m}$ w.e. (water equivalent) and $-0.35 \mathrm{~m}$ w.e., respectively. Only two years have resulted in positive balance. Kongsvegen, however, has a larger area at higher altitudes than the other measured glaciers, and the mean net balance over the twelve years period has been slightly positive, $+0.11 \mathrm{~m}$ w.e. The area/altitude distribution of the ice masses is important for their sensitivity to climate changes.

The Equilibrium Line Altitude (ELA) is the altitude where ablation equals accumulation or where all the winter snow, but no more, is melted in summer. The ELA of Kongsvegen is about 100 $m$ higher than the ELA of Austre Brøggerbreen and Midre Lovénbreen. Satellite data have also been used to study glacier characteristics and positioning of the ELA on these glaciers (Winther 1993). This is an index of relative continentality, which increases from west to east. Between sea level and $500 \mathrm{~m}$ a.s.l., Kongsvegen receives a little less snow than the glaciers located further west in the fjord, and higher atmospheric temperature in summer leads to more melting.

There are no calculations of the balance of the large glacier, Kronebreen $\left(700 \mathrm{~km}^{2}\right)$. Rough estimates give a net surface balance between -0.10 and $-0.15 \mathrm{~m}$ w.e., but due to the iceberg calving (see below) the net balance is more markedly negative.

As shown in Fig. 7, there is little year-to-year

Table 2. Mean specific glacier balance values, total run-off and volume change.

\begin{tabular}{lcccccc}
\hline $\begin{array}{l}\text { Glacier } \\
\text { (period) }\end{array}$ & $\begin{array}{c}\text { Bw } \\
(\mathrm{m} \text { w.e. })\end{array}$ & $\begin{array}{c}\mathrm{bs} \\
(\mathrm{m} \text { w.e. })\end{array}$ & $\begin{array}{c}\mathrm{bn} \\
(\mathrm{m} \text { w.e. })\end{array}$ & $\begin{array}{c}\text { ELA } \\
(\mathrm{m} \text { a.s.1. })\end{array}$ & $\begin{array}{c}\text { Annual } \\
\text { meltwater } \\
\text { production } \\
\left(\mathrm{m}^{3}\right)\end{array}$ & $\begin{array}{c}\text { Annual } \\
\text { volume } \\
\text { change } \\
\left(\mathrm{m}^{3}\right)\end{array}$ \\
\hline $\begin{array}{l}\text { Austre Brøggerbreen } \\
(1967-1998)\end{array}$ & 0.69 & -1.14 & -0.45 & 417 & 5700 & -2260 \\
$\begin{array}{l}\text { Midre Lovénbreen } \\
(1968-1998)\end{array}$ & 0.73 & -1.08 & -0.35 & 396 & 6500 & -2100 \\
$\begin{array}{l}\text { Kongsvegen } \\
(1987-1998)\end{array}$ & 0.79 & -0.74 & +0.11 & 505 & 75000 & +11500 \\
\hline
\end{tabular}


Fig. 7. Annual mass balance of Austre Brøggerbreen and Kongsvegen. The net balance (bn) is the sum of accumulation (bw) and ablation (bs).

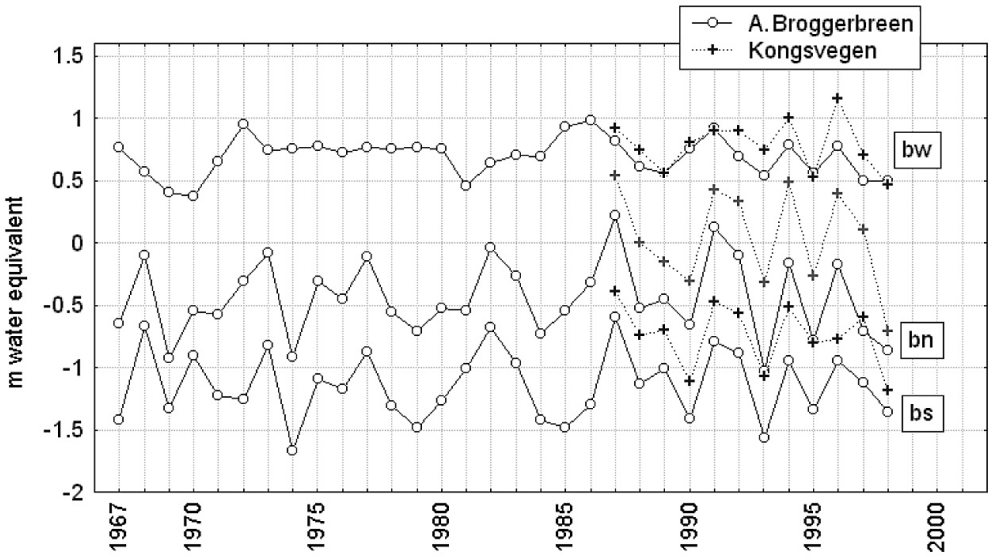

variation in the winter balance and high variation in the summer balance, showing that the summer temperature mainly drives the interannual variability in the net balance. There is no trend in the net balance, nor in the winter and summer balances, over the observation period. This corresponds well with a lack of observed trend in the atmospheric temperature.

Based on meteorological data, one empirical model indicates that an increase of $1^{\circ} \mathrm{C}$ in the atmospheric summer temperature will induce a net balance of -0.7 and $-0.55 \mathrm{~m}$ w.e. for Austre Brøggerbreen and Midre Lovénbreen, respectively, while the glaciers may reach a new equilibrium with a summer temperature decrease of $0.7^{\circ} \mathrm{C}$ (Lefauconnier et al. 1993). The model does not take into account the effect of the gradual change in glacier area. Energy balance modelling shows similar results (Flemming et al. 1997). In the event of climate warming, higher precipitation and melting rates are anticipated, and therefore the transfer of water to the fjords is expected to increase.

\section{Flow velocity - calving rate}

The flow rate of Svalbard glaciers is generally low due to the low ice temperatures. In general, glaciers ending on land flow much slower than calving glaciers. Measurements indicate that the maximum surface velocity is about $2 \mathrm{~m}, 4.5 \mathrm{~m}$ and $7 \mathrm{~m}$ per year for Austre Brøggerbreen, Midre Lovénbreen and Austre Lovénbreen, respectively. The ice velocities of Blomstrandbreen and Conwaybreen are not known. With a velocity of between 2 and $3 \mathrm{~m} \mathrm{a}^{-1}$ all over its basin, Kongs- vegen is a slow moving glacier. The neighbouring Kronebreen is a fast flowing glacier. The accumulation area of Isachsenfonna moves $0.2 \mathrm{~m} \mathrm{~d}^{-1}$ (or about $70 \mathrm{~m} \mathrm{a}^{-1}$ ) over a distance of $25 \mathrm{~km}$, and the velocity of Holtedahlfonna increases from near zero at the top to $0.5 \mathrm{~m} \mathrm{~d}^{-1}\left(180 \mathrm{~m} \mathrm{a}^{-1}\right)$ at $15 \mathrm{~km}$ from the calving front (Lefauconnier et al. 2001). The mean annual velocity in the central part of the front of Kronebreen is $2 \mathrm{~m} \mathrm{~d}^{-1}$, with a peak of $4.5 \mathrm{~m} \mathrm{~d}^{-1}$ at the beginning of July. The high velocities indicate that basal sliding is important and that the glacier sole is at the melting point. Such conditions must lead to a substantial amount of water discharge and sediment transport to the fjord. The annual front movement $\left(800 \mathrm{~m} \mathrm{a}^{-1}\right)$, together with the retreat of the front, induces an important calving comprising between 0.20 and $0.25 \mathrm{~km}^{3} \mathrm{a}^{-1}$ (Lefauconnier et al. 1994). Due to the bathymetry beneath the glacier tongue, velocity and calving rate are expected to decrease slightly in the coming 30 to 50 years.

Kronebreen delivers only small icebergs or bits to the fjords. Some of the largest bergs regularly strand on the eastern part of the Lovénøyane or on the threshold, which delimits the boundary between the inner and intermediate fjord. Icebergs are also frequently stranded on the northern part of this threshold between the Lovénøyane and Blomstrandhalvøya.

\section{Surges}

Surging glaciers are widespread in the study area. In a non-surging glacier, there is an approximate balance between accumulation above the ELA and the ice flux into the ablation 
area. Hence, the glacier maintains a near steady state longitudinal profile. In a surge-type glacier, the ice flux is smaller than the accumulation in the quiescent phase. Thus, the surface gradient gradually increases, causing the basal shear stress to increase in turn. When the shear stress reaches a critical (but unknown) value, a surge commences and sliding increases rapidly. The surge results in a large ice flux from the higher to the lower part of the glacier, usually accompanied by a rapid advance of the glacier front. Often, the surge is also accompanied by considerable sub-glacial water and sediment flux and, in the case of tidewater glaciers, by increased iceberg production. When the climate is stable, surges are not triggered by climatic variations, and the morphological evidence of past glacier maximum extent is not necessarily directly linked to climatic conditions, but rather indicate a surge advance (Lefauconnier \& Hagen 1991).

Various surveys and morphological observations indicate that all the calving glaciers have surged and that the cirque glaciers Pedersenbreen, Midre Lovénbreen and Austre Brøggerbreen have probably surged. Kongsvegen is building up towards a surge at the moment, but it is difficult to predict when a new surge will be triggered (Melvold \& Hagen 1998).

\section{Change in front positions}

The glaciers in Kongsfjorden had their maximum Holocene extent in the last part of the 18th century and started to retreat around 1900 (Liestøl 1988). Since then the retreat has been almost continuous, only interrupted by some surge advances. For the glaciers ending on land, well-preserved ice-cored moraines clearly indicate the maximum extent. These glaciers have retreated between 1 and $2 \mathrm{~km}$ over the last 100 years. The tidewater glaciers both retreat and advance much faster. The maximum extent is more difficult to locate precisely, but can be mapped from sub-sea moraines (Whittington et al. 1997) and direct observations. Liestøl (1988) studied old maps and expedition notes and made maps of the maximum positions and retreats of all calving fronts in the fjord.

The maximum extent of Blomstrandbreen occurred at an unknown date probably before 1861. Since then the total retreat has been about 3 $\mathrm{km}$. Advances of the front due to surges of Blomstrandbreen itself or of its tributaries occurred between 1907 and 1928 as well as around
1960. Since then, annual submarine moraines deposited after the last event indicate a mean retreat rate of $35 \mathrm{~m} \mathrm{a}^{-1}$. The front retreated from Blomstrandhalvøya in 1992, and the retreat rate has increased since then. Today there is a passage of more than $500 \mathrm{~m}$ between the glacier front and the island.

The maximum extent of Kronebreen in 1869 was about $11 \mathrm{~km}$ beyond the present day front. Over the last 50 years the front has retreated about $150 \mathrm{~m} \mathrm{a}^{-1}$.

The maximum position of Conwaybreen, which occurred ca. 1870-1880, probably corresponds to a submarine moraine ridge about $3.5 \mathrm{~km}$ from today's front. Since then, the glacier has undergone a regular retreat, apart from a probable limited advance between 1936 and 1948.

\section{Freshwater discharge into Kongsfjorden}

The four main sources for freshwater run-off are glacier ablation, snowmelt, and summer rainfall and ice calving. The main freshwater input to the fjord occurs in the summer season, mainly as melting of snow and ice. The inflow comes from point sources such as outlet channels from the glaciers.

The input data for run-off calculations are: 1) run-off measurements in Bayelva; 2) meteorological data from Ny-Ålesund; and 3) mass balance measurements on Austre Brøggerbreen, midre Lovénbreen and Kongsvegen.

Empirical regression approach-As mentioned above, the glacier mass balance measurements have provided information about the precipitation gradient and the melt rate gradient by altitude and can therefore be used to estimate the total freshwater input to Kongsfjorden. In combination with digital elevation models, these gradients have been used to estimate the run-off contribution from the different sources as well as

Table 3. Mean annual run-off from different sources.

\begin{tabular}{lcc}
\hline Source & Specific $(\mathrm{mm} / \mathrm{area})$ & Total $\left(10^{6} \mathrm{~m}^{3}\right)$ \\
\hline Qi & $530(300-755)$ & $766(437-1096)$ \\
Qs & $53(44-62)$ & $77(64-90)$ \\
Qp & $206(180-250)$ & $300(260-360)$ \\
Qb & $172(138-207)$ & $250(200-300)$ \\
Qg & 0 (unknown but small) & 0 \\
Qc & 10 & 12 \\
Qe & -20 & -29 \\
Qtotal & $951(652-1264)$ & $1376(944-1829)$ \\
\hline
\end{tabular}


the total amount. The freshwater input to the fjord system can be estimated and discussed from the following water balance equation:

$$
\mathrm{Q}=\mathrm{Q} s+\mathrm{Qp}+\mathrm{Qi}+\mathrm{Qb}+\mathrm{Qg}+\mathrm{Qc}-\mathrm{Qe}
$$

where $\mathrm{Q}$ is the potential total run-off, Qs is snowmelt from ice-free areas, $Q p$ is run-off from rainfall, Qi is the glacial component of discharge which includes ice-melt, firn-melt and snowmelt from the ice-covered areas, $\mathrm{Qb}$ is fresh water from icebergs calving from the glaciers, Qg is groundwater discharge, Qc is condensed water vapour and $\mathrm{Qe}$ is evaporation. The last three sources are small and provide together an almost negligible contribution. Applying this to the small basin of Bayelva, where both run-off and mass balance are measured, indicates that the glacier mass balance data provide a reliable estimate of the run-off (Hagen \& Lefauconnier 1995).

By this method, the current mean annual total run-off to Kongsfjorden is estimated to be about $950 \mathrm{~mm} \mathrm{a}^{-1}$, or about $1370 \times 10^{6} \mathrm{~m}^{3}$, or close to $1.4 \mathrm{~km}^{3}$. The year-to-year variations are large, about $30 \%$ (Table 3 ).

The annual freshwater input from Bayelva alone is calculated to be $7 \times 10^{6} \mathrm{~m}^{3}$ (Hagen \& Lefauconnier 1995).

Modelling approach - - Based on observations of temperature and precipitation, the terrestrial run-off response can be calculated using a precipitation-run-off model. Such a model called the HBV model (Bergström 1972) has been calibrated and applied successfully to several catchments on Svalbard (Bruland \& Sand 1994). Calibrated parameters for these catchments are very similar, indicating comparable hydrological conditions in spite of large distances between them and the very different extents of glaciation. It is therefore likely that these conditions are comparable over large areas of Svalbard. Assuming that representative meteorological observations are available, the model can therefore be used successfully for a large number of catchments

Table 4. Annual simulated run-off to the Kongsfjorden basins $\left(10^{6} \mathrm{~m}^{3}\right)$.

\begin{tabular}{lcccc}
\hline Year & $\begin{array}{c}\text { Kronebreen, } \\
\text { and } \\
\text { Kongsvegen }\end{array}$ & $\begin{array}{c}\text { Lovén- and } \\
\text { Pedersen } \\
\text { glaciers }\end{array}$ & Bayelva & $\begin{array}{c}\text { Total to the } \\
\text { Kongsfjorden } \\
\text { basins }\end{array}$ \\
\hline Max. & 1100 & 57 & 43 & 1200 \\
Min. & 450 & 23 & 20 & 493 \\
Mean & 800 & 42 & 32 & 874 \\
\hline
\end{tabular}

on Svalbard. The advantage of using a model like this is that daily run-off can be calculated from daily observations of temperature and precipitation, and run-off can be predicted for days to come based on weather forecasts. Based on meteorological observations in Ny-Ålesund, annual run-off to the Kongsfjorden basins was calculated using this model (Table 4).

\section{Sea ice conditions}

\section{Ice concentration}

Data on sea ice extent in Kongsfjorden (i.e. spring seasons 1981-83, 1985-86: Mehlum 1991; spring 1984: Lydersen \& Gjertz 1986) indicate that the break up of the sea ice cover occurs between April and July. These data and observations by Gerland (unpubl.), between 1997 and 2001, show high interannual variation of the position of the ice edge and the timing of melting and break up. However, no systematic monitoring of the sea ice situation in Kongsfjorden has been carried out; the above-mentioned studies therefore give only an indication of the conditions occurring in certain years. A Landsat TM satellite image reveals the sea ice extent in Kongsfjorden and Krossfjorden on 5 May 1998 (Fig. 8). In 1998, the sea ice extent in Kongsfjorden was above average in spring, with the ice edge in the south located near Ny-Ålesund until mid June; even so, another Landsat image (15 July 1998) shows relatively little sea ice in the fjord. Wind, waves and tides create a highly variable ice situation in the middle part of the fjord in spring. The situation can change completely within a few hours. Large waves entering the fjord from the west break up the ice cover, and subsequent easterly winds will efficiently remove large amounts of ice in Kongsfjorden. In 1997, 1998 and 2000, the inner part of the fjord was completely covered with fast ice until the onset of melt. The outer part of the fjord was either ice-free or covered with drift ice (ice concentration between $1 / 10$ and 8/10). In both May 1997 and 2000, the fast-ice edge in the southern part of the fjord was located near the Lovénøyane. These islands also constrained the ice edge position in April 1984 (Lydersen \& Gjertz 1986), July 1981, June 1982, 1983, 1985 and 1986 (Mehlum 1991) (Fig. 8). West of the Lovénøyane, the fjord was open or covered by drift ice. Often, the concentration of drift ice was 


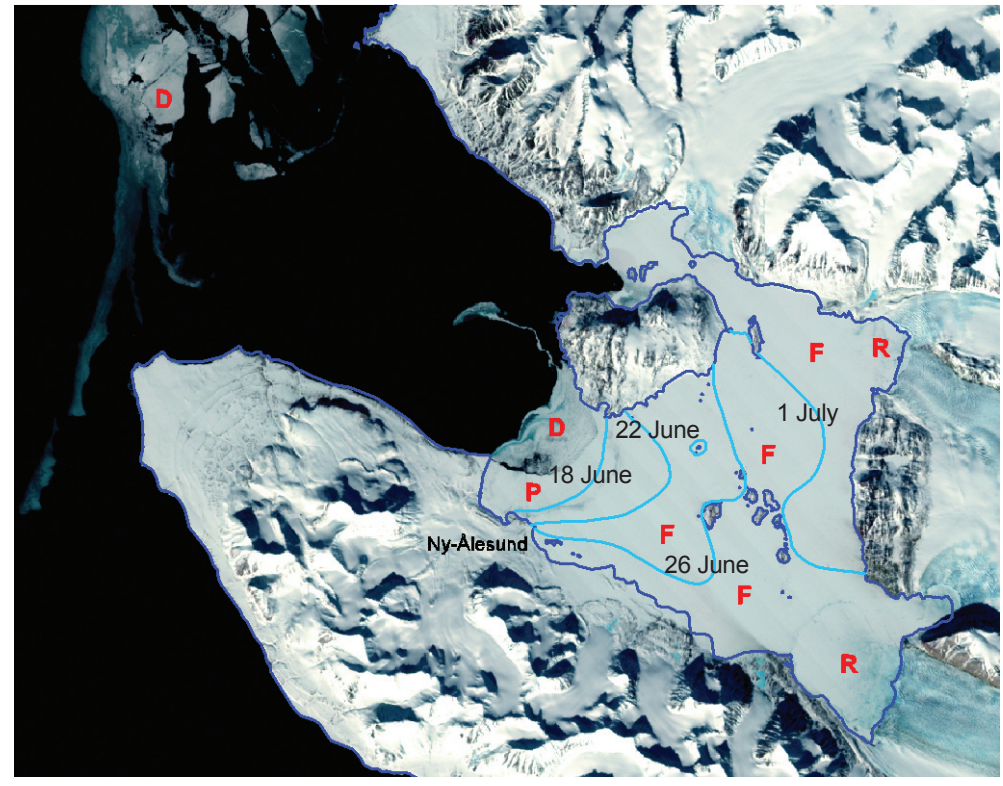

Fig. 8. Landsat TM image of Kongsfjorden, taken 5 May 1998 (channels 4, 3 and 2). Dark blue lines show present coastlines, and light blue lines represent sea ice edges in summer 1986, on dates indicated (Mehlum 1991). On 22 June, there was also some open water around the island Eskjeret. Note that at that time, the channel north of Blomstrandøya was still obstructed by the glacier Blomstrandbreen, which since then has retreated further north, as can be seen from the satellite image from 1998. Sea ice types are indicated as D: drift ice; P: pack ice; F: undisturbed fast ice; and R: rafted and ridged fast ice with icebergs and blocks. Ice types were assigned using both the satellite image and visual observations on site. observed to be patchy or aligned in stripes along the fjord. In the north, the fast ice in May 1997 extended to the coast of Blomstrandhalvøya, near Elefantsteinen. This area was free of firstyear fast ice in 2000, and was covered only by drift ice or young grey ice. The area even became entirely ice-free occasionally during the spring. In 2001, sea ice formation started very late, and only the inner part of the fjord was covered with ice (inner zone 4 in Fig. 1b in Hop et al. 2002). Most of Kongsfjorden remained open throughout the winter and spring, which is considered as an exceptional case.

\section{Ice types}

The dominant ice type in Kongsfjorden in winter is young ice, later in early spring it is first-year fast ice, and after the onset of melting it is a combination of fast ice and drift ice. In addition, icebergs and ice pieces from surrounding glaciers can be found frozen into the fast ice or drifting in open water. The latter is a typical situation once all fast ice disappears in summer.

Fast ice.-Some details about the fast ice in Kongsfjorden from 1997 and 1998 are given by Gerland et al. (1999a). Due to the geometrical setting of Kongsfjorden, first-year fast ice is the dominant sea ice type in Kongsfjorden in early spring. The ice thickness at Dyrevika at the end of the freezing season was observed to be about
$70 \mathrm{~cm}$ in 1997 and $60 \mathrm{~cm}$ in 1998, and the snow layer on top of the ice in both years was about $20 \mathrm{~cm}$ thick at the onset of the melt. Very little lateral thickness variations were observed. The ice consisted of a granular ice layer near the surface $(\mathrm{ca} .11 \mathrm{~cm})$ and columnar ice below a $2 \mathrm{~cm}$ thick transitional zone. The latter exhibited very long, regular crystals, indicating undisturbed ice growth.

Young ice.-Early in winter, a large portion of the fjord surface is covered with young ice, which immediately affects the energy exchange between the atmosphere and ocean. Young ice was also observed later in spring. It forms during short periods when sheltered areas in the inner part of the fjord (e.g. between or on the lee side of the islands Lovénøyane) become ice free due to wind, waves or currents.

Drift ice.-Specific meteorological conditions combined with tidal currents can lead to large amounts of drift ice in the fjord. Floes typical vary in size between 1 and $10 \mathrm{~m}$, and they originate from either fast ice in Kongsfjorden or Krossfjorden, or from ice that has been formed outside the fjord system. Distribution of drift ice in Kongsfjorden may change very fast. In the ice characterization (Fig. 8), a distinction is made between drift ice (D) and pack ice (P). Here, drift ice corresponds with "very open pack ice", and pack ice represents drift ice that has been pushed together by wind and currents, 
Fig. 9. Photograph taken on the fast ice in Kongsfjorden in spring 1997, showing level sea ice and frozen-in freshwater ice pieces originating from surrounding glaciers. Photo: S. Gerland.

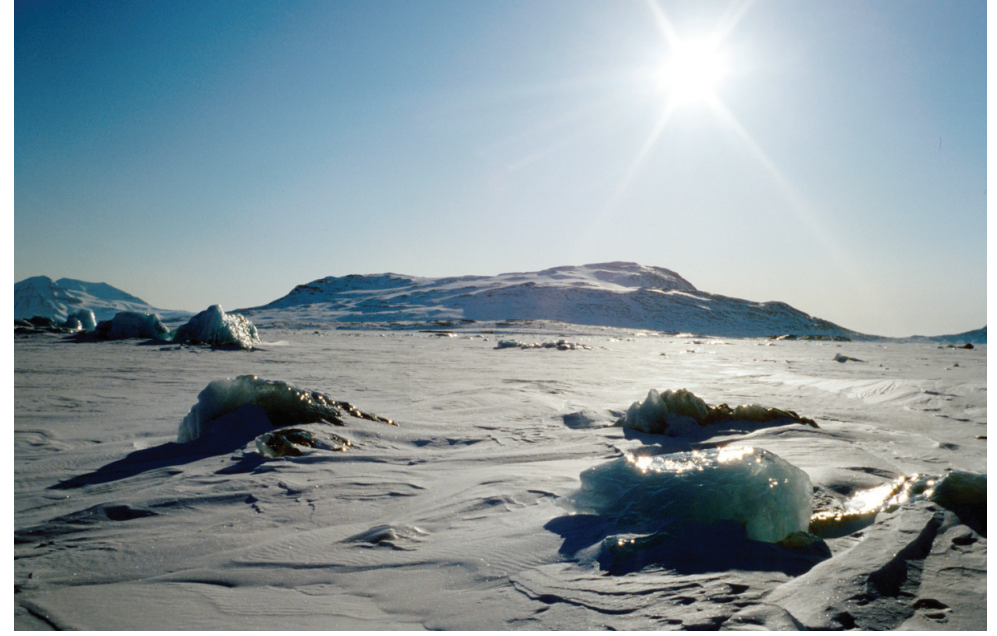

the ice porosity was observed to be increasing significantly within one month, whereas the ice thickness decreased only little (Gerland et al. 1999a). Comparably thin fast ice during spring (about $25 \%$ of corresponding fast ice thicknesses in northern Canada; Brown \& Cote 1992) can be accounted for late and slow freezing and ice growth, due to mild air temperatures and the warm water influence from the WSC (Gerland \& Winther 2000).

Ice-surface flooding, ponds.-In spring, ponds and holes first develop around icebergs and large freshwater ice pieces frozen into the fast ice. Once the ice reaches negative freeboard, surface flooding by seawater occurs (Gerland et al. 1999a). The break-up and final vanishing of the fast ice is facilitated by the formation of cracks and pores in the ice.

Formation of snow ice and superimposed ice.Formation of snow ice or superimposed ice, as it is known, e.g. from the Antarctic (e.g. Eicken 1992), was also observed in Kongsfjorden in late May and early June 1998 (Gerland et al. 1999a). This layer changes the surface properties of the ice and could also influence biota associated with the sea ice environment.

\section{Physical oceanography}

\section{Forcing mechanisms}

Interactions between forces governing the fjord circulation, coupled with the complex bottom topography and coastline, result in a complicated 
flow pattern and distribution of different water masses within the fjord system. There are variations in the forcing on a wide range of time scales, the major ones being the year-to-year variations in atmospheric climate conditions and heat transport in the WSC, the seasonal change in radiation from the sun, the wind varying over time scales of days, and the daily tidal variations. The following description of circulation conditions is based on summer field investigations in 1995, made by the Geophysical Institute, University of Bergen (GIUB) (hydrographic mapping with CTD and current drifters) and between 1996 and 2000 by the Institute of Oceanology, Polish Academy of Science (IOPAS) (hydrographic mapping with undulating CTD, and ship-mounted Acoustic Doppler Current Profiler [ADCP]). In addition, the Princeton Ocean Model (Blumberg \& Mellor 1987) was applied to simulate the upper layer circulation in response to the two local forcing mechanisms, wind and freshwater run-off. The model is a three-dimensional, primitive equation, $\sigma$-coordinate model with free surface and a flat bottom at depth $100 \mathrm{~m}$ (for detailed description see Ingvaldsen et al. 2001). In reality, most of the fjord is deeper than $100 \mathrm{~m}$, but the bottom depth variation is not likely to affect the surface circulation, particularly not in the summer when there is a strongly stratified brackish layer. The turbulent momentum transfer from the wind is not able to penetrate the stable pycnocline present during the summer, and the wind forcing affects only the low density surface layer which "slides" on top of the pycnocline independently of the deeper circulation. The wind effect penetrates deeper in situations of less stable stratification, but will still affect mainly the upper layer, which is an order of magnitude smaller than the depth of the fjord system.

The tide travels as a transient Kelvin wave along the west Spitsbergen coast (Gjevik \& Straume 1989). The tide inside the KongsfjordenKrossfjorden system is a response to the tidal elevation of the ocean surface outside the fjord where the amplitude is about $0.5 \mathrm{~m}$. The dominant component is the semi-diurnal lunar $\left(M_{2}\right)$, but there is also a solar component $\left(S_{2}\right)$, which constitutes about $50 \%$ of the $M_{2}$ component, causing the amplitude to vary considerably during the fortnightly spring-neap period. There is also an even smaller diurnal tidal $\left(\mathrm{K}_{1}\right)$ component in the area (Kasajima \& Svendsen in press), which in some parts of the shelf generates shelf waves.
These waves are characterized by oscillations in the current but hardly any in surface elevation. Recent measurements (not published) indicate that such oscillations can also be found in Kongsfjorden, possibly as a response to shelf wave motion on the adjacent shelf.

Winds at the west Spitsbergen coast cause Ekman drift to either pile up or remove surface water from the coast. The result is an altering of the stratification of the water outside the fjord system in the form of down-welling or up-welling. This builds up a horizontal pressure gradient between the coast and the fjord system, forcing water in or out of the fjord area. Conservation of volume demands that exchange takes place in both directions.

It is evident that the exchanged coastal water also includes AW. Since AW in the WSC is constrained by geostrophy to flow along the shelf slope, the flux of AW water towards the fjord mouth must be a consequence of ageostrophic processes in the Arctic Front, which marks the boundary between the WSC and the ArW (shelf water). Like the shelf-fjord exchange, measurements across the front indicate that the exchange in the frontal area takes place on varying temporal and spatial scales.

Inside the fjord system, the circulation is strongly influenced by the Coriolis effect because the fjord width exceeds the baroclinic (internal) Rossby radius of deformation. In a two layer model the definition of this parameter is $a_{i}=c_{i} / f$, where

$$
c_{i}^{2}=\frac{g^{\prime} H_{1} H_{2}}{H}
$$

is the phase speed of the baroclinic wave,

$$
g^{\prime}=g \frac{\rho_{2}-\rho_{1}}{\rho_{2}}
$$

is the reduced gravity, $\rho_{1}, \rho_{2}$ and $H_{1}, H_{2}$ are densities and depths of the upper and lower layer respectively, $\mathrm{H}=\mathrm{H}_{1}+\mathrm{H}_{2}$ is the total depth and $f$ is the Coriolis parameter. A summer situation simplified by a two-layer model with $\rho_{1}=1026.4 \mathrm{~kg} \mathrm{~m}^{-3}, \rho_{2}=1026.4 \mathrm{~kg} \mathrm{~m}^{-3}, H_{1}=30$ $\mathrm{m}$ and $H_{2}=220 \mathrm{~m}$ gives a rough estimation of $a_{i} \approx 4 \mathrm{~km}$, about half the average width of the Kongsfjorden. Similar values ranging from 3 to $4 \mathrm{~km}$ were obtained on basis of the vertical density profiles observed every summer in 19962000 in the middle basin. Generally, the currents tend to turn to the right, and the tidal response is a tidal Kelvin wave propagating with land to 
the right around the fjord. According to Kelvin wave theory the tidal current also is along lateral boundaries (coastlines).

\section{Upper layer circulation}

The seasonal variation in freshwater input creates a very stable stratification in summer and very weak stratification in winter. Atmospheric heating during summer and cooling during winter enhance this effect. The upper layer circulation in summer is confined to a shallow surface layer.

Field investigations by researchers from the IOPAS and additional field investigations and model simulations by the GIUB allow a general description of the brackish flow, transporting the meltwater down-fjord. In most cases, the 34 psu isohaline reaches the fjord outlet at a depth of a few metres whereas the 33 psu isohaline outcrops at the surface within the fjord basin, manifesting the frontal area between coastal and fjord surface waters. In the inner basin, the salinity of the upper layer of both fjords drops below $30 \mathrm{psu}$ at the surface. Usually the thickness of the upper layer bordered by the 33 psu isohaline is a few metres. The speed of the brackish current, measured in July 1999 in the constriction between the inner and middle basin, ranges from 10 to $30 \mathrm{~cm} \mathrm{~s}^{-}$ 1 (confirmed by many drifter experiments, e.g. Fig 13). The down-fjord advection of freshened water is maintained throughout the whole tidal period, but the tide modifies the strength of the flow. Maximum velocity is an effect of superimposed tidal-, freshwater- and wind-driven currents. A rough estimation of the freshwater transport, assuming advection with speed of $20 \mathrm{~cm} \mathrm{~s}^{-1}$ within a surface layer of 5-m thickness, an average salinity of $32.8 \mathrm{psu}$, and using a reference salinity of open sea waters equal to 34.9 gives ca. $200 \mathrm{~m}^{3} \mathrm{~s}^{-1}$ taking in to account the width of the measured constriction. Considering that $90 \%$ of the freshwater is supplied to the fjord during three summer months, we obtain its volume equal to ca. $1800 \times 10^{6} \mathrm{~m}^{3}$, confirming the maximum estimates given in Table 3 . (However this value is probably overestimated because of the assumption of a steady downfjord surface flow.) Small amounts of brackish water, not considered above, flow through the opening between Blomstrandhalvøya and the glacier Blomstrandbreen. This branch of the brackish water stream flows partly farther along the northern side of Kongsfjorden and partly recirculates around Blomstrandhalvøya, where it can be identified as a small pattern of cold and less saline water entering the inner fjord at the northernmost side of the constriction.

The interactive effects of freshwater and local wind are illustrated by model runs. The simulated freshwater driven case (Fig. 10a) reveals a flow pattern down-fjord that is confined to the northern side in the outer basin. This flow is intensified under the down-fjord wind when the brackish current is also narrower and more confined to the northern side (Fig. 10b). Since down-fjord winds prevail over the area (see Fig. 4), this would be the predominant situation during summer. This is manifested in the surface salinity distribution observed 15 August 1995, which was established by a down-fjord wind (Fig. 11a ). The brackish flow along the northern coast of Kongsfjorden can be clearly recognized. A strong current component to the northern side is also clearly apparent in drifter experiments (Fig. 11b). A similar dynamic response to the wind is also seen in Krossfjorden where the downfjord flow follows the western side of the fjord. The simulations indicate an active interaction between the fjord arms.

Simulations of the model with up-fjord wind give up-fjord surface currents (Fig. 12) stacking up the brackish water at the fjord head, which subsequently results in the development of an across-fjord front and a down-fjord pressure gradient. The down-fjord pressure gradient eventually becomes strong enough to overcome the wind action and turn the flow down-fjord. A sudden relaxation of the wind would likely set up an internal seiche, which may cause shearinduced mixing. Stigebrandt (1976), however, showed theoretically that a seiche in Oslofjorden would not survive more than one oscillation. This has also been observed, e.g. by Svendsen (1969). The up-fjord winds are rare and short-lasting events, as indicated by Fig. 4, but one evidence for such a flow pattern is the development of a front between the fresher and the more saline surface waters in August 1995 (Fig. 13a). The drifter vectors in the constriction show up-fjord flow enhanced to the right (Fig. 13b).

Observations of the brackish flow, e.g. in July 2000 , show how the joint effect of wind- and wave-induced mixing and entrainment from the underlying, more saline fjord waters, erode the upper layer, leading to a higher salinity and a deeper brackish layer in the outer part of the 

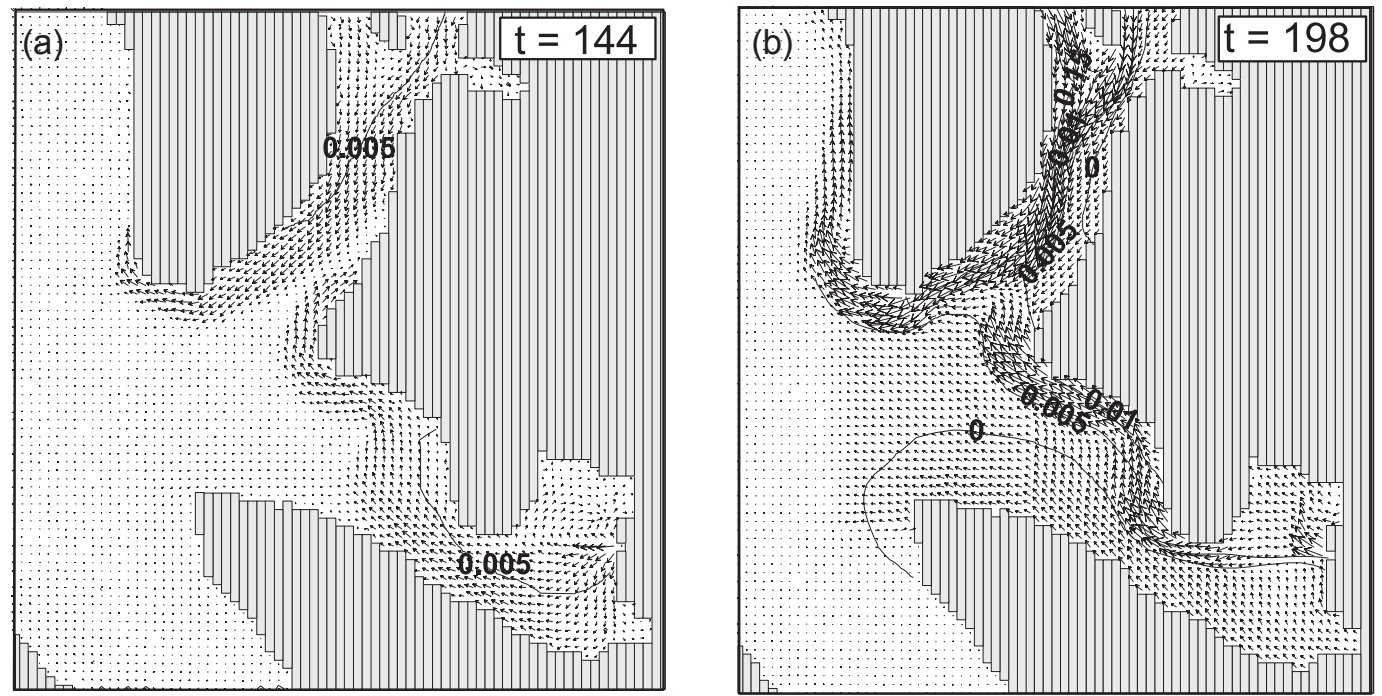

Fig. 10. Simulated surface circulation patterns. (a) Freshwater-driven with run-off from three sources, $55 \mathrm{~m}^{3} \mathrm{~s}^{-1}$ from the head of Kongsfjorden and $15 \mathrm{~m}^{3} \mathrm{~s}^{-1}$ from the head of each of the two fjord arms in Krossfjorden. Simulation time is 144 hours. (b) Freshwater and down-fjord wind-driven with the same run-off and with wind speed of $6.5 \mathrm{~m} \mathrm{~s}^{-1}$. Simulation time is 198 hours. The wind forcing is present for the last 6 hours. Surface height coutours are given in $0.005 \mathrm{~m}$ intervals.
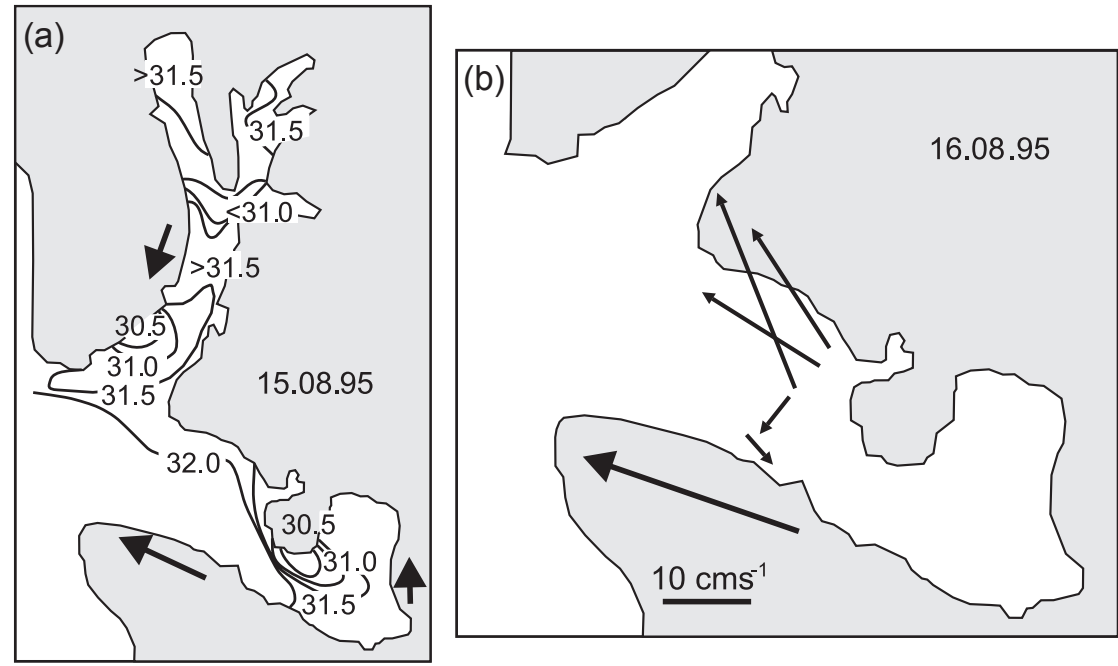

Fig. 11. (a) Surface salinity distribution and (b) surface current during a period with down-fjord wind in 1995. The heavy arrows on land represent the wind conditions during the mapping (rough scale: $\left.1 \mathrm{~cm}=4 \mathrm{~m} \mathrm{~s}^{-1}\right)$.

fjord. The rotational effects can also create a cross-fjord gradient in the layer thickness; the depth of $34 \mathrm{psu}$ isohaline deepened from $5 \mathrm{~m}$ at the southern coast to almost $20 \mathrm{~m}$ at the northern side of the outer part of Kongsfjorden. The autumn cooling destabilizes the stratification and this increases the effect of wind mixing, which further destabilizes the water column.

In winter, usually only part of the fjord is covered with sea ice because of the exchange with warm AW near the coast. The wind does not directly affect the circulation in the icecovered area, but it may indirectly set up a circulation under the ice cover. The most typical wind direction out of the fjord removes surface water from the ice edge, creating a horizontal down-fjord pressure gradient under the ice cover. This gradient may drive water out from the icecovered area, setting up a return flow that may supply Atlantic influenced water to the underside 

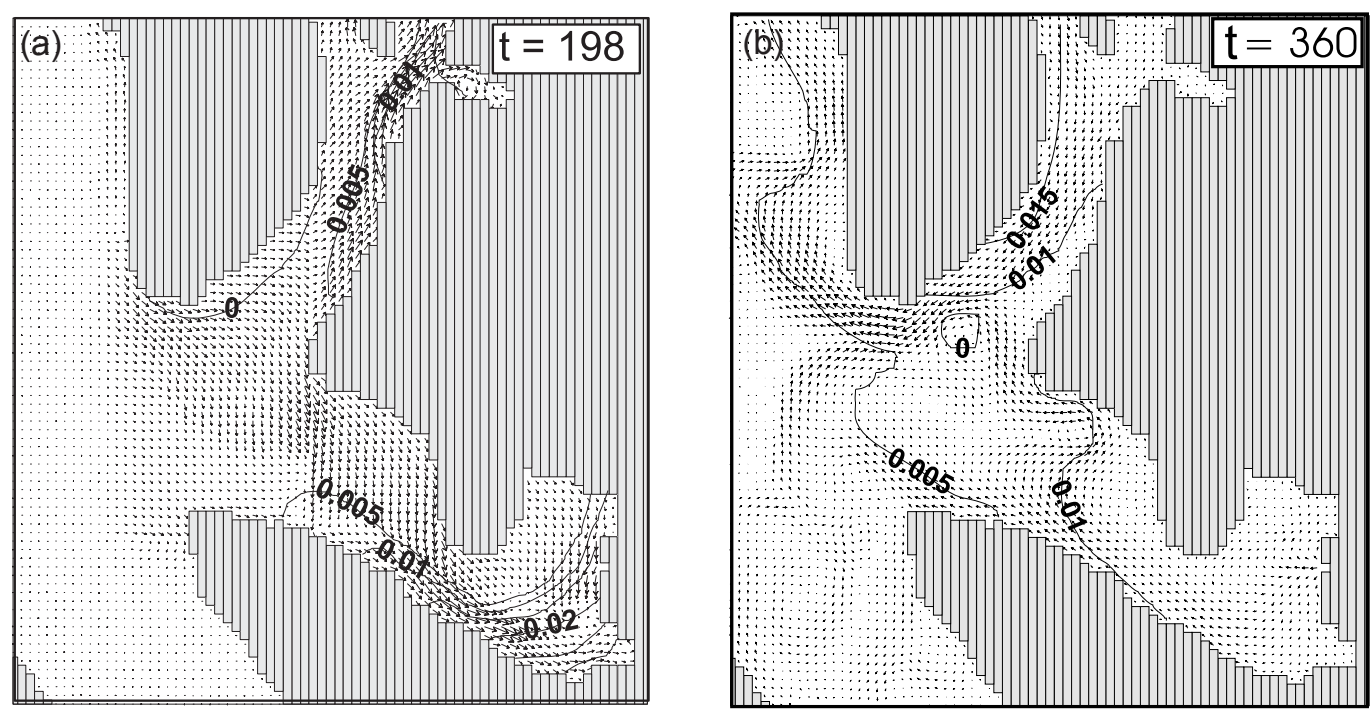

Fig. 12. Simulated surface circulation pattern: freshwater and up-fjord wind-driven with the same run-off and wind speed as in Fig. 10 after (a) 198 hours and (b) 360 hours of simulation time. The wind forcing is present in the period of $192-240$ hours. The Surface height coutours are given in $0.005 \mathrm{~m}$ intervals.
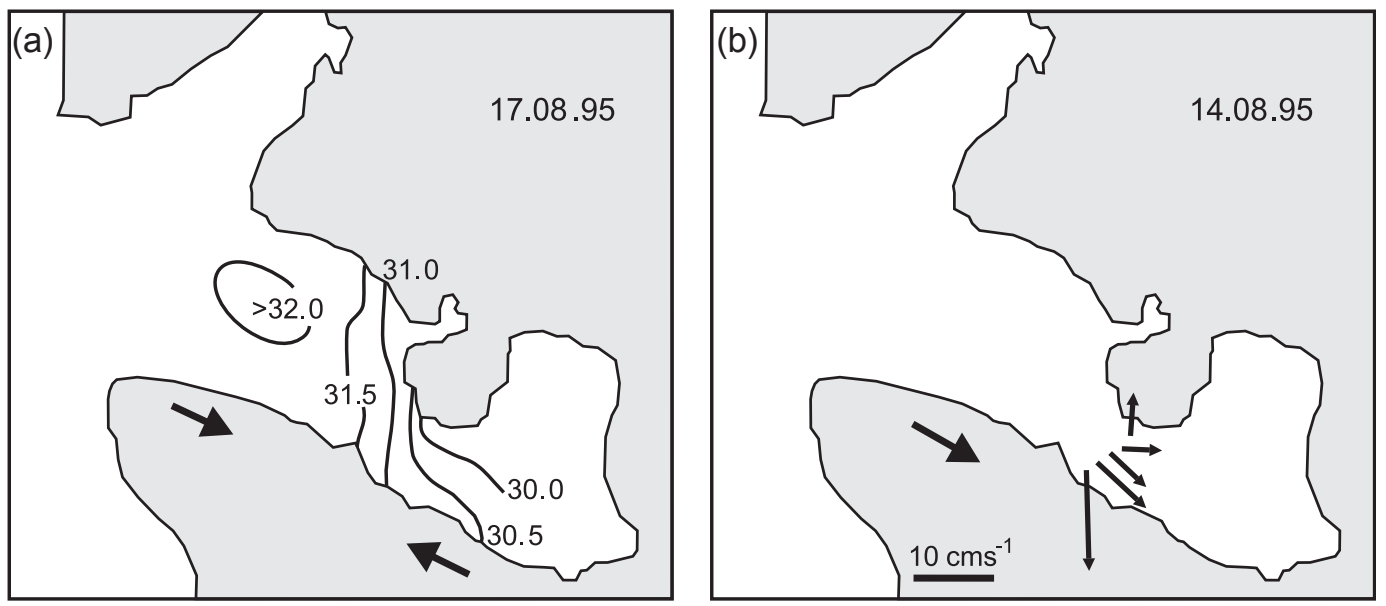

Fig. 13. (a) Surface salinity distribution and (b) surface current during a period with up-fjord wind in 1995. The heavy arrows on land represent the wind conditions during the mapping (rough scale: $1 \mathrm{~cm}=4 \mathrm{~m} \mathrm{~s}^{-1}$ ).

of the ice cover and thereby slow down the speed of ice growth (Gerland \& Winther 2000).

The areas near glacier fronts are extremely active. Developments of small-scale turbulent eddies and vortex filaments, were observed within $50-100 \mathrm{~m}$ of the glacier face during field measurements in summer 1999 and 2000. The most intensive turbulent eddies with diameters of a few metres were commonly found in close proximity to direct outflows from the front of Kongsbreen. Sharp fronts, separating waters with different concentrations of suspended matter were clearly visible at the surface. A strong surface current meandered along the glacier front with a maximum speed exceeding $1 \mathrm{~m} / \mathrm{s}$. Patches of strong turbulent mixing were 


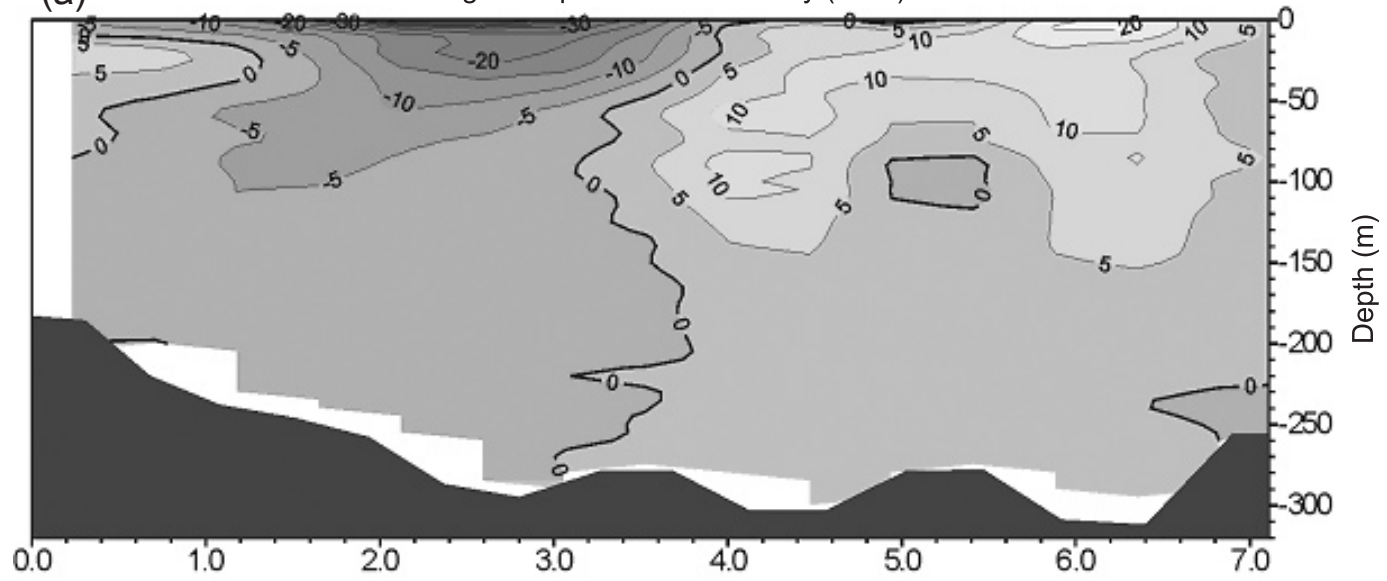

(b) ADCP-measured current velocity $(\mathrm{cm} / \mathrm{s})$

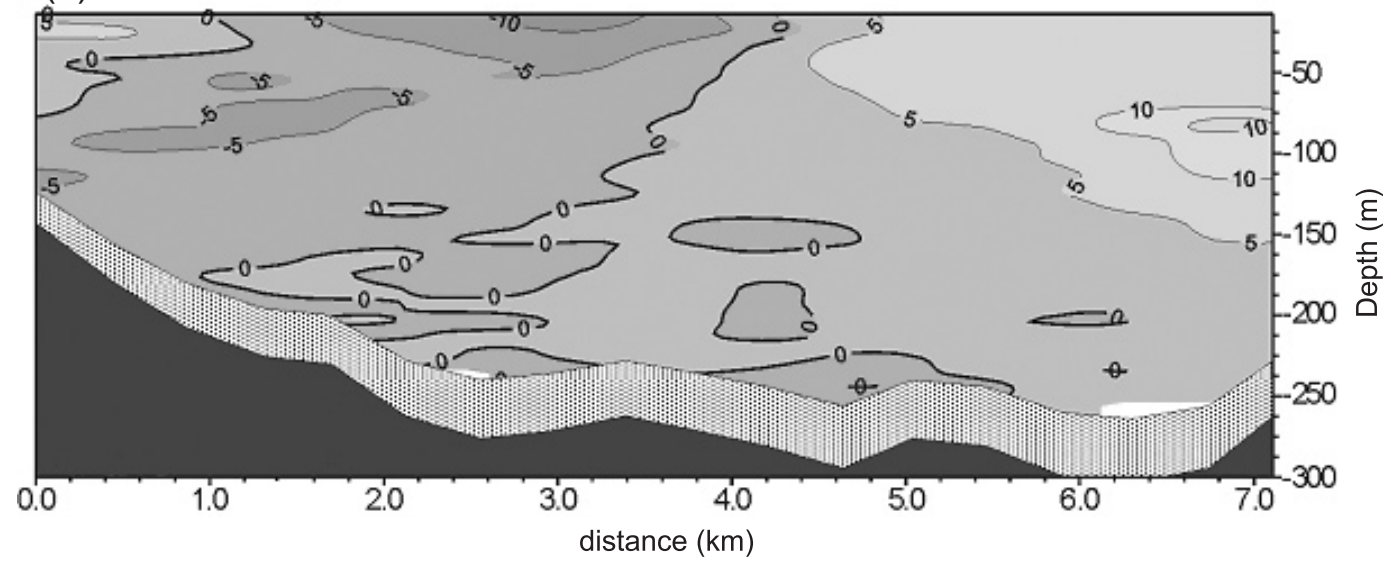

Fig. 14. (a) Calculated baroclinic geostrophic and (b) ADCP-measured current distribution at a section across the middle basin of Kongsfjorden, measured in July 1999. Positive values are up-fjord.

also distinguishable. These active areas contained an abnormal amount of dead plankton in the upper layer and a great abundance of feeding seabirds (Hop et al. 2002).

Repeated sections along the glacier front revealed a gradual cooling of the water northward, with maximum temperatures of $3-4^{\circ} \mathrm{C}$ found in the southern part at the surface or sometimes in the intermediate layers. Patches with decreased temperature were observed at the intermediate depths (10-30 m), similar to "cold tongues" reported in Antarctic fjords (Domack \& Ishman 1993). Heat loss results when seawater comes in contact with the glacier wall or the meltwater influx from ice melting. Greisman (1979) showed that heat fluxes between seawater and glacier face $(q)$, and thus ice melt rate, are strongly dependent upon elevation of the seawater temperature over the temperature at the glacier face $(\Delta T)$ and only weakly upon a vertical length scale $l_{z}$ (glacier draft), according to the formula $q \propto(\Delta T)^{7 / 5} l_{z}^{1 / 5}$. In Kongsfjorden, $\Delta T$ reaches $5-6^{\circ} \mathrm{C}$ indicating intense melting along the glacier face. Melting of glacial ice and the resulting buoyant plume can also result in upwelling near the glacier face. The direction of the temperature drop along the glacier is a clear evidence of the cyclonic circulation in the inner basin.

\section{Deep water currents}

Remote forcing at the Spitsbergen coast (tide and 
coastal winds) give rise to an internal Kelvin wave propagating into the fjord system. The established current is aligned in the direction of wave propagation with highest speed and surface elevation along the right border. A considerable decrease in speed and surface elevation occurs leftward in the cross-fjord direction if the flow width is comparable to the Rossby radius of deformation, defining the rotational effect. In stratified fjords, such as Kongsfjorden, this effect becomes significant. As a result water is stacked up at the southern coast of the inner basin. A pressure gradient is set up across the fjord and forces the wave to continue around the basin and out at the northern side.

Because of the strong pycnocline, circulation in the deep layers can be, to some extent, independent from the upper layer flow. In July 1999, a great volume of AW was observed in the middle basin and a disturbance caused by a Kelvin wave, travelling around the fjord with the coast to the right, was distinguishable at a cross-fjord section measured with an ADCP (Fig. 14). This pattern can be also seen in the distribution of baroclinic geostrophic currents, computed from the density field with the bottom as a reference level (Fig. 14). In both cases, an up-fjord flow about $4 \mathrm{~km}$ wide, comparable to the local Rossby radius, was found at the southern coast, while the opposing, down-fjord current occurred along the northern side of the fjord. Measured velocities were not higher than $8-10 \mathrm{~cm} \mathrm{~s}^{-1}$. On other occasions, development of cyclonic eddies with diameters comparable to the fjord's width, were observed at cross-fjord ADCP sections in the middle basin. Such eddies are probably characteristic of the circulation pattern in this part of the fjord.

As was mentioned above, the Kelvin wave enters the inner basin along the southern coast and forces an outflow at the northern side. An ADCP section, measured repeatedly 15 times during 22 hours in the constriction between NyÅlesund and Blomstrandhalvøya, confirmed this two-directional layout of currents. The velocities of the opposing flows were highly variable, up to $10 \mathrm{~cm} \mathrm{~s}^{-1}$ in the intermediate layer. The width of the prevailing stream changed periodically and the up-fjord flow in the southern part of the constriction was less stable than to the downfjord outflow along the northern coast. The net volume transport across the whole section, comprising the layer below $20 \mathrm{~m}$ (therefore excluding the surface flow), was revealed to be closely correlated with the tidal height (Fig. 15). Both the tidal and wind-driven currents vary substantially from place to place in the fjord system. While strong stratification in the summer months confines wind-driven currents to the upper layer, the tidal components, which are strongly influenced by topography, affect the whole water column and also modify the upper layer flow. Rough estimates indicate that tidal currents have velocities of a few $\mathrm{cm} \mathrm{s}^{-1}$ in the middle basin and are intensified in the shallow inner basin. In general, the observed wind-driven velocities were 2-3 times higher.

Water exchange with the coastal area is a very complex process driven by different mechanisms (see e.g. Svendsen 1977, 1981; Cannon \& Holbrook 1981; Klinck et al. 1981; Proehl \& Rattray 1984; Stigebrandt 1990) and only qualitative estimates are possible based on our data. Some ADCP sections across the Kongsfjorden outlet revealed an up-fjord directed flow at the southern side with maximum velocities of about $6-8 \mathrm{~cm} \mathrm{~s}^{-1}$ measured in the layer occupied by the AW. There is no shallow sill at the fjord's entrance and the ratio between its cross-sectional area and the total fjord volume is on the of order $10^{-1} \mathrm{~m}^{-1}$. Thus, advection of shelf waters is not confined by topography and AW can be transported directly into the deep layers in Kongsfjorden. A hypothetical rate of advection of Kongsfjorden water towards the coastal area was estimated to be ca. $5 \mathrm{~cm} \mathrm{~s}^{-1}$, based on seaward displacement of the fjord origin intrusion of freshwater from the drainage basin, as observed twice in 1999. In that case, an outflow of fjord water was found in the intermediate layer between 50 and $110 \mathrm{~m}$, reaching to a range of $15 \mathrm{~km}$ from the fjord mouth. Most often the fjord water outflows at the northern coast but it was also observed in the central part of the outlet.

Great amounts of warm AW, transported by the WSC, were apparent in Kongsfjorden in summer 1999, when the whole volume of the outer basin below $120 \mathrm{~m}$ depth was filled with AW. However, the highest values of salinity in the fjord waters were observed in summer 1998, although the amount of AW found in the WSC core at the latitude of Kongsfjorden was less than it was one year later. In this case, AW was transported onto the shelf via numerous intrusions as well as within the near-bottom layer of about $50 \mathrm{~m}$ thickness. Thus, the volume of water of Atlantic origin in Kongsfjorden is related not only to 


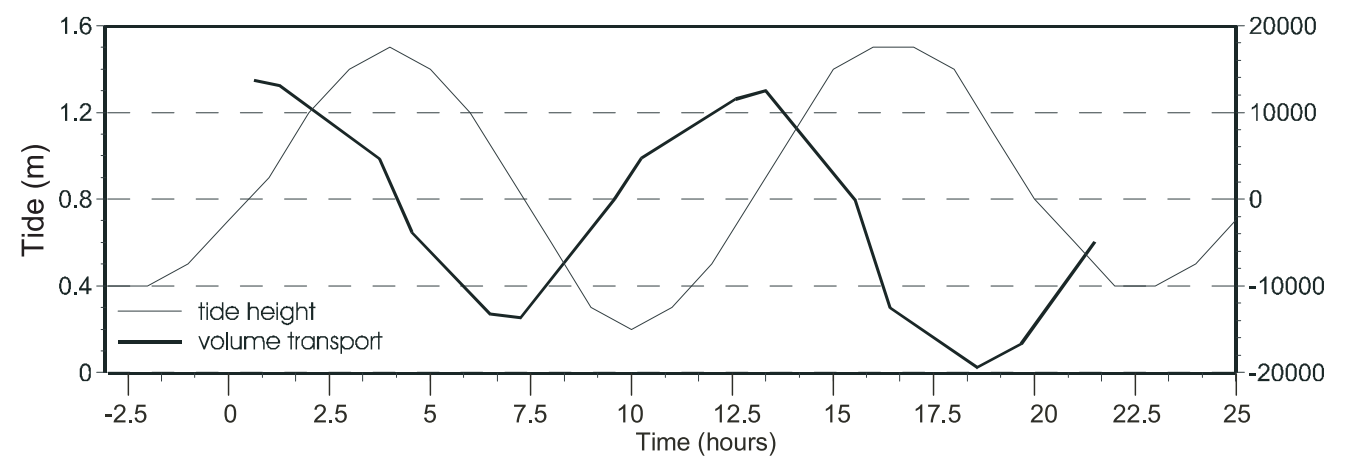

Fig. 15. Time series of tidal height and net volume transport across the constriction between the inner and outer parts of Kongsfjorden, measured in July 1999.

the amount of AW in the WSC core but also to stability of the WSC flow and the front separating the WSC from shelf waters. The main cause of the cross-shelf transport of AW is topographic steering and irreversible cross-front exchange caused by barotropic front instability (Saloranta \& Svendsen 2001).

The Atlantic influence on species composition in Kongsfjorden is outlined in Hop et al. (2002).

\section{Water masses}

A generally accepted classification of water masses in the Nordic seas, proposed by Swift (1986) and Hopkins (1991), defines the characteristic values of the AW transported by the WSC as temperature $>3{ }^{\circ} \mathrm{C}$ and salinity $>34.9 \mathrm{psu}$. The shelf waters are also influenced by the cold and less saline ArW, transported in the upper layer by coastal currents flowing northward around southern and western Spitsbergen (Fig. 1). Outflow from the fjords situated further south also contributes to the salinity drop in the shelf waters. As a result of mixing processes, the AW entering Kongsfjorden differs significantly from the water in the core of the WSC and can be regarded as Transformed Atlantic Water (TAW), with decreased values of temperature and salinity $\left(\mathrm{T}>1{ }^{\circ} \mathrm{C}, \mathrm{S}>34.7 \mathrm{psu}\right)$.

During every summer between 1996 and 2000, TAW with salinity values between 34.7 and $34.96 \mathrm{psu}$ and temperatures higher than $1{ }^{\circ} \mathrm{C}$ was observed in Kongsfjorden. However, there is a significant year-to-year variability in the volume and characteristics of the TAW. In 1996 and 1997, TAW with temperatures not higher than $1.5^{\circ} \mathrm{C}$ was found in the outer fjord; this was only slightly warmer then local fjord waters. In the next two years, 1998 and 1999, a large amount of the warm AW $\left(\mathrm{T}>2{ }^{\circ} \mathrm{C}, \mathrm{S}>34.7\right)$ filled the whole deep layer below ca. $130 \mathrm{~m}$ (for 1999, see Fig. 16a, c). A completely different situation occurred in 2000 (Fig. 16b, d), when an intrusion of warm and highly saline water occupied the main outlet within a layer between 90 and $250 \mathrm{~m}$, but only small isolated patches of TAW were observed in the outer basin of Kongsfjorden. In general, the horizontal extent of TAW is practically limited by the sill between the inner and outer basins.

The low temperature $\left(\mathrm{T}<1^{\circ} \mathrm{C}\right)$ Local Water (LW) mass spreads mostly over the Atlantic origin water. In the outer basin, LW can also be found in the deep and bottom layer since TAW intrudes the fjord at the intermediate depths. LW is produced directly in the fjord by convectional processes during autumn/winter cooling. It is also formed near the glacier face, when the warmer water flowing along the ice wall gradually cools and slowly sinks. In the outer part of Kongsfjorden, the LW has salinity similar to TAW ( $\mathrm{S}>34.4 \mathrm{psu}$ ), whereas in the inner basin a drop in salinity of LW occurs as a result of meltwater input. Extremely low temperatures, reaching $-1.4^{\circ} \mathrm{C}$ and high salinity were found in the deep depressions near the glacier walls. They were filled with the Winter Cooled Water mass (WCW; $\mathrm{T}<-0.5^{\circ} \mathrm{C}, \mathrm{S}>34.4 \mathrm{psu}$ ), produced as a result of winter cooling, sea ice formation and the sinking of dense, very cold water in a deep convection process. The WCW can occupy the isolated bottom depressions throughout the year. This process is analogous to the brine formation in Storfjorden (Quadfasel et al. 1988; Piechura 1996). 


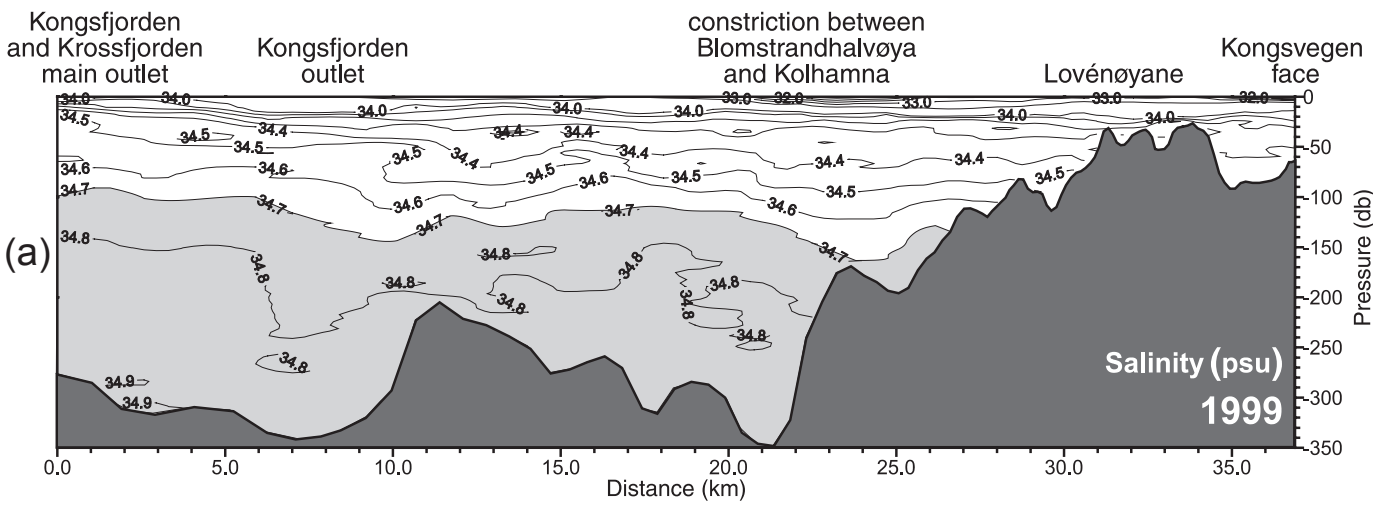

(b)
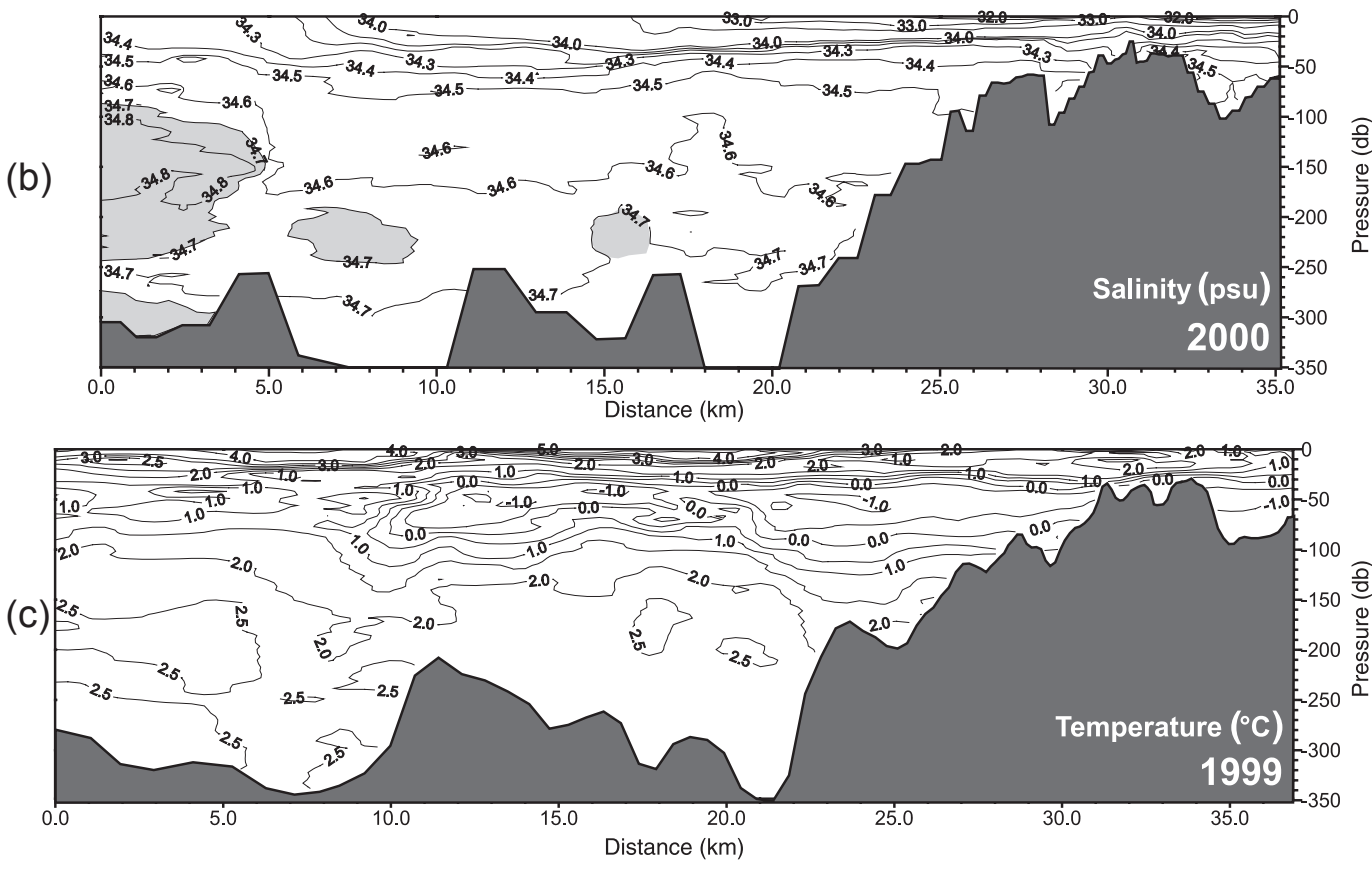

(d)

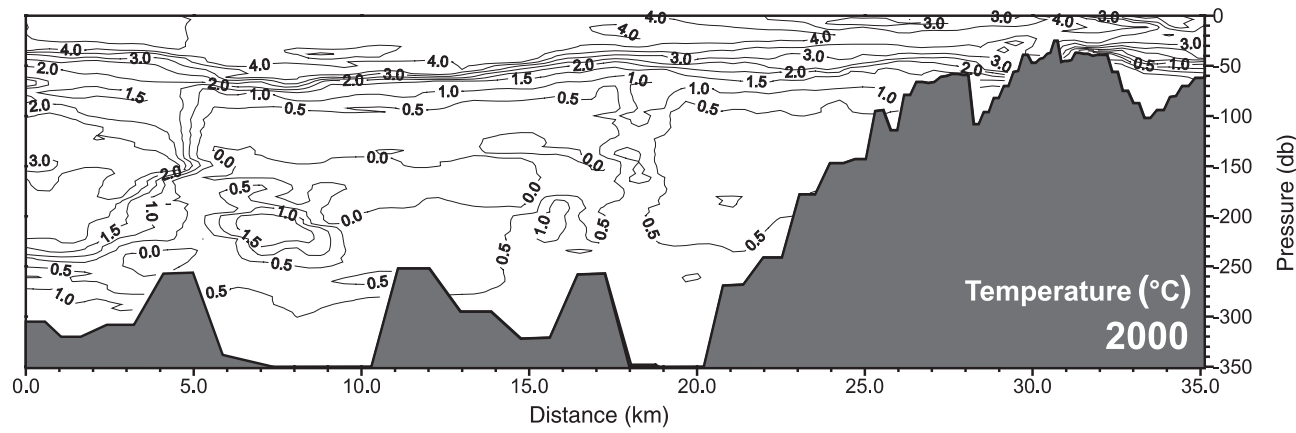

Fig. 16. Distributions of salinity (a, b) and temperature (c, d) along Kongsfjorden's axis in the middle of July 1999 and 2000.
Abbreviations for water masses used in this paper:
ArW Arctic Water
AW Atlantic Water
SW Surface Water
TAW Transformed Atlantic Water
IW Intermediate Water
WCW Winter Cooled Water
LW Local Water 
A decreased salinity characterizes the Surface Water (SW), which drops to $30 \mathrm{psu}$ in the middle fjord and below 28 psu in the inner basin near the glaciers. This brackish water occupies several metres of the upper water column, but the layer decreases in thickness towards the fjord mouth. In Kongsfjorden's inner basin, meltwater from glacier ablation results in the development of a freshened surface layer with a sharp vertical salinity gradient. Melting of fast ice and icebergs from glacier calving, common in the inner fjord, contributes to dilution of the upper layer and results in a subsurface decrease of temperature. A relatively thin layer (ca. 2-3 m) of melted glacier water, extending over the whole fjord surface, contains a large amount of suspended matter and undergoes fast heating from solar radiation. In the period 1996-2000 (data for July) the highest surface temperature was observed in the middle basin and exceeded $4^{\circ} \mathrm{C}$, except in 1998 , when it was ca $1-2^{\circ} \mathrm{C}$ lower. Although river discharge in Spitsbergen fjords is generally of secondary importance relative to glacier ablation, strongly freshened and relatively warm plumes of riverine water are usually formed near river outlets. Their vertical extent is confined to the upper 2-3 m. Due to this significant freshwater input, the SW in the fjord system is characterized by lower salinity compared to the typical Arctic SW found in the coastal area.

Above the TAW is a transitional layer of Intermediate Water (IW) with salinity $34<\mathrm{S}<34.7 \mathrm{psu}$ (characteristic values lower than in TAW but usually higher than in freshened surface waters). It develops through processes of heat exchange between the surface waters and the underlying layers as well as a commonly occurring cold subsurface layer. Entrainment of higher salinity water into the surface layer and mixing processes further contribute to the development of TAW. A layer of IW with $\mathrm{T}>1{ }^{\circ} \mathrm{C}$ often spreads over the cold LW, especially in Kongsfjorden's inner basin. This layer's thickness is on the order of tens of metres, varying significantly along the fjord axis.

Volume and spatial distribution of TAW and LW in Kongsfjorden as well as thickness and range of SW layer are characterized by significant interannual variability. The difference in TAW volume in 1999 and 2000 (Fig. 16) probably resulted from a smaller amount of AW transported by the WSC in 2000 than in 1999 (IOPAS, unpubl. data) and, to greater extent, from the prevailing coastal wind direction, favourable for intensified water exchange in 1999 (see section on forcing mechanisms).

\section{Suspended particulate matter and sedimentation processes}

\section{Water column}

Studies on the concentration and composition of suspended particles in the water column of west Spitsbergen fjords have been carried out chiefly by IOPAS (Weslawski et al. 1993; Zajaczkowski 1997; Zajaczkowski \& Legazynska 2001) and Norwegian universities. More recently, the extent of scavenging processes, fluxes and resident times of particles have also been investigated by the Italian ENEA Marine Environment Research Centre (Papucci et al. 1998; Papucci et al. 1999). Unless otherwise stated, the information below derives from IOPAS and ENEA, including new, unpublished data. Carried out mostly in April through September for logistical reasons, all these studies suffered from a limitation in seasonality. The data therefore relate to this early spring - late summer period.

The concentration of suspended particulate matter in Kongsfjorden is mainly a reflection of the activity of glaciers, which bring meltwater and inorganic particles into the fjord (BeszczyeskaMøller et al. 1997). The concentration of total suspended solids and the extent of the sedimentation processes in the different parts of the fjord have a direct influence on some key characteristics of the fjord system (Elverhøi et al. 1980; Elverhøi et al. 1983; Eisma 1986; Görlich et al. 1987; Eilertsen et al. 1989; Sexton et al. 1992; Gonzalez et al. 1994), such as: a) the extent of the euphotic zone and its consequence for primary production; $b$ ) heat exchange with the atmosphere; c) flocculation of colloids and aggregation of particles (influence on carbon flux); d) direct impact on organisms living both in the water column and in surficial sediments; and e) physical-chemical and geotechnical properties of the sea floor.

Particle concentrations have been estimated by filtration of seawater on $0.45 \mu \mathrm{m}$ acetate and 0.7 $\mu \mathrm{m}$ glass-fibre filters, at the end of April and May 1996 and July 1998. The weight of dry mass of total suspended solids and organic solids (ash free dry weight) was determined by the combusting method described by Dean (1974). Fluxes of 
particulate inorganic matter (PIM) and particulate organic matter $(\mathrm{POM})$ were determined with cylindrical sediment traps of $100 \mathrm{~mm}$ diameter and $700 \mathrm{~mm}$ length. The sediment traps were placed at depths of $5,15,30$ or $50 \mathrm{~m}$ on the stations located at 2.9, 4.2, 6.8, 8.2 and $9.4 \mathrm{~km}$ from the glacier in spring, and 0.25, 2.9, 4.2, 6.8, 8.2 and $11.8 \mathrm{~km}$ in summer. Particulate organic carbon and nitrogen were measured in accordance with methods delineated by Hadges \& Stern (1984). In addition, the radioactive disequilibrium of ${ }^{234} \mathrm{Th} /$ ${ }^{238} \mathrm{U}$ was used as a tracer for estimating the flux of total suspended solids and the residence times of particulate thorium, mimicking the behaviour of the particulate matter (Papucci et al. 1999). The results showed a strong seasonal trend, mainly related to the coverage of the fjord by fast ice and first-year pack ice in the cold season (Haldal \& Haldal 1973; Keck 1999), and to calving and melting of glaciers during the summer.

In spring (April-May), the highest concentration of suspended PIM was observed in the inner part of the fjord (Fig. 17), reaching more than $20 \mathrm{~g} \mathrm{~m}^{-3}$ in surface water under the fast ice. In the central part of the fjord $(8.2 \mathrm{~km}$ from the glacier), the concentration of PIM increased from 1 to $20 \mathrm{~g} \mathrm{~m}^{-3}$ in the depth interval $0-25 \mathrm{~m}$. The highest spring flux of PIM $\left(>15 \mathrm{~g} \mathrm{~m}^{-2} \mathrm{~d}^{-1}\right)$ was observed at $4-6 \mathrm{~km}$ from the glacier front at $15 \mathrm{~m}$ depth, probably in relation to organic flocculation or reflocculation processes (Eisma 1986; Dyer 1989). High concentrations of POM (20 - $\left.26 \mathrm{~g} \mathrm{~m}^{-3}\right)$ were observed throughout the spring season in the upper part of the water column of inner part of the fjord. A relatively low ratio between particulate organic carbon/nitrogen (POC/PON $=5.9-6.5$ ) was measured in spring, suggesting high concentration of algal cells in the euphotic zone (Hop et al. 2002). The POM concentration decreased to $<2 \mathrm{~g} \mathrm{~m}^{-3}$ near the bottom. The fluxes of POM were $<0.5 \mathrm{~g} \mathrm{~m}^{-2} \mathrm{~d}^{-1}$ at the end of April, and slowly increased to $4 \mathrm{~g} \mathrm{~m}^{-2} \mathrm{~d}^{-1}$ at the end of May. The low rate of POM sedimentation is possibly related to the advection and the stratification of the water column which results from glacier activity, as described for Nordåsvannet, a land-locked fjord in western Norway (Wassmann 1985).

During the summer, the horizontal distribution of PIM showed a sharp peak, up to $340 \mathrm{~g} \mathrm{~m}^{-3}$ at the glacier front, and a slow decrease from $25-30 \mathrm{~g} \mathrm{~m}^{-3}$ at the glacier proximal zone to $<20 \mathrm{~g} \mathrm{~m}^{-3}$ about $10 \mathrm{~km}$ away. The highest
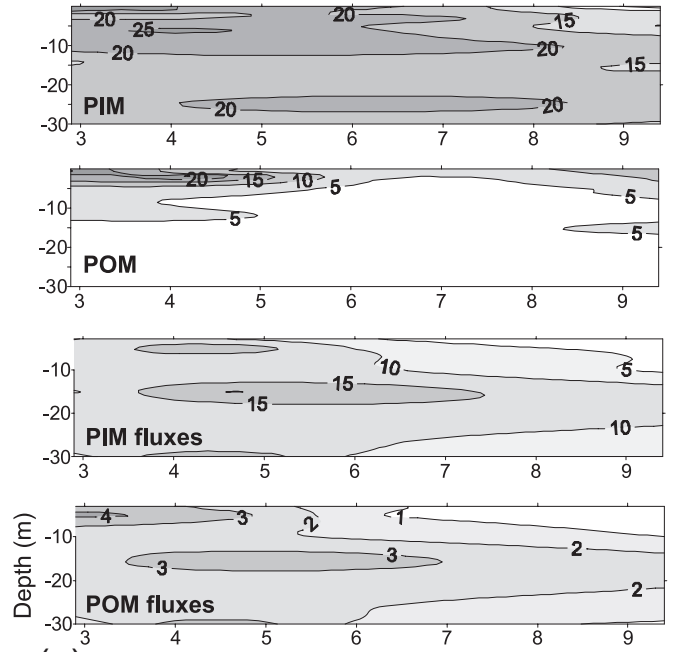

(a)

Distance from glacier front $(\mathrm{km})$
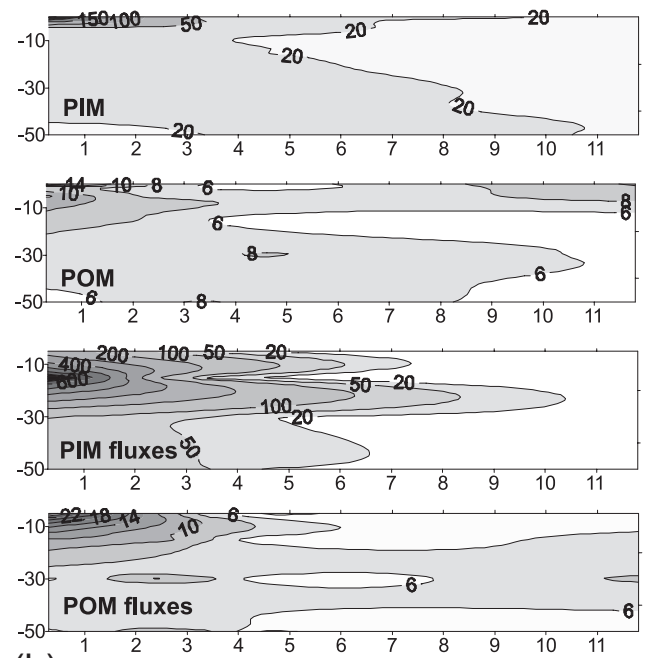

(b) Distance from glacier front ( $\mathrm{km})$

Fig. 17. Concentrations of suspended matter. (a) Particulate inorganic matter (PIM) $\left(\mathrm{g} \mathrm{m}^{-3}\right)$, particulate organic matter (POM) $\left(\mathrm{g} \mathrm{m}^{-3}\right)$, and PIM and POM fluxes $\left(\mathrm{g} \mathrm{m}^{-2} \mathrm{~d}^{-1}\right)$ collected in May 1998. (b) The same, measured in July 1998.

flux of PIM (800 $\left.\mathrm{g} \mathrm{m}^{-2} \mathrm{~d}^{-1}\right)$ was observed at $15 \mathrm{~m}$ depth, in front of Kongsbreen, but it never exceeded $20 \mathrm{~g} \mathrm{~m}^{-2} \mathrm{~d}^{-1}$ in the central part of the fjord. The POM fluxes range from $25 \mathrm{~g} \mathrm{~m}^{-2} \mathrm{~d}^{-1}$ at the Kongsbreen glacier front in the upper part of water column to $<6 \mathrm{~g} \mathrm{~m}^{-2} \mathrm{~d}^{-1}$ in the central part of the fjord. The enhanced POM sedimentation at the glacier front could be a result of upwelling of 


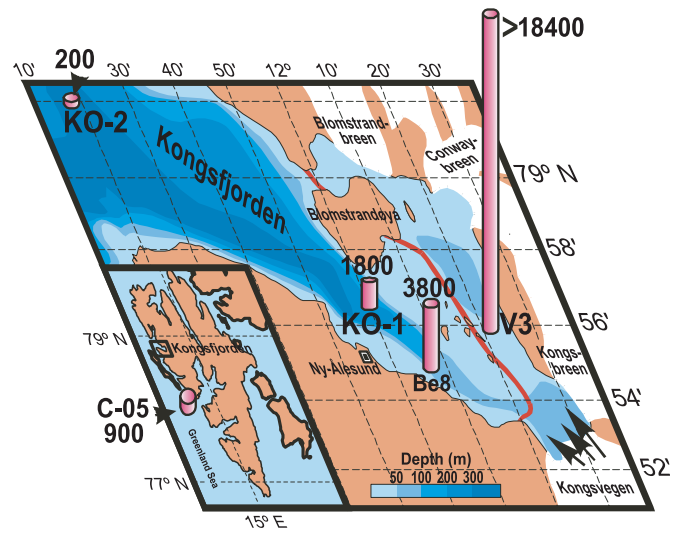

Fig. 18. Sedimentation rates $\left(\mathrm{g} \mathrm{m}^{-2} \mathrm{y}^{-1}\right)$ in Kongsfjorden.

underlying water (which is richer in organisms; Hop et al. 2002) caused by meltwater discharge, producing a low-salinity stratum at the surface. The organisms transported by the upwelled water usually die from osmotic shock when exposed to low-salinity water, and then sink (Weslawski \& Legezynska 1998).

In late summer (September) the Total Suspended Solid (TSS) load was about $1 \mathrm{~g} \mathrm{~m}^{-3}$. The residence time and flux of particulate matter in the water column in this same period was determined using the ${ }^{238} \mathrm{U} /{ }^{234} \mathrm{Th}$ disequilibrium method, tracing particle dynamics on a time scale of $<100$ days. The results (late summer, central Kongsfjorden) showed: a) a flux of TSS ranging between 7 and $18 \mathrm{~g} \mathrm{~m}^{-2} \mathrm{~d}^{-1}$; and b) residence time of particulate ${ }^{234} \mathrm{Th}$ of 20-23 days, which is in good agreement with the value of 18-29 days obtained analysing the chlorophyll-a biomass residence time from the sediment traps (Keck 1999). Similar results have been obtained by Langone et al. (1997) (residence times 7-8 days, particle flux 1.2-5.0 $\mathrm{g} \mathrm{m}^{-2} \mathrm{~d}^{-1}$ ) close to a retreating seasonal ice margin in the Ross Sea, Antarctica. In ice-covered open sea, Cochran et al. (1995) calculated a higher value of residence time (52-293 days) in the north-east water polynya of Greenland.

\section{Sediments}

The ${ }^{210} \mathrm{~Pb}_{\mathrm{ex}}$ dating technique has been used to determine the fraction of settling particles which accumulates on the seafloor (Goldberg 1963; Koide et al. 1973). The sediment cores were
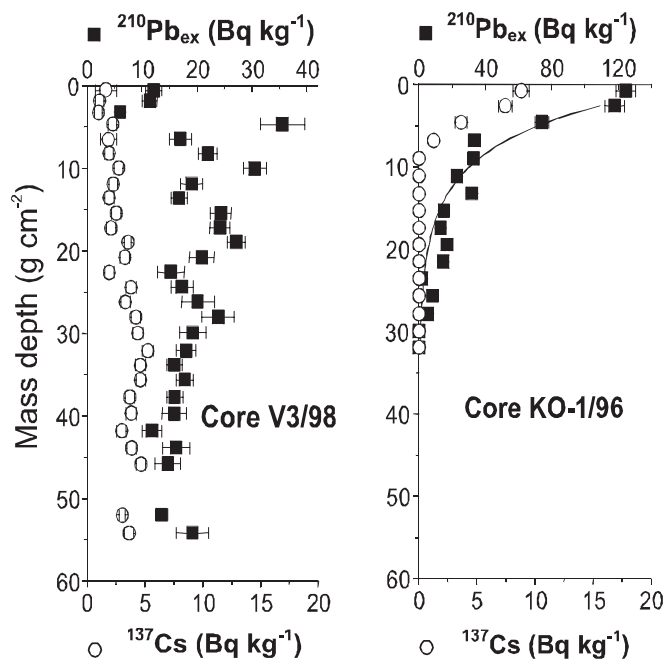

Fig. 19. Vertical distribution of the anthropogenic radionuclide ${ }^{137} \mathrm{Cs}$ and the natural radionuclide ${ }^{210} \mathrm{~Pb}_{\mathrm{ex}}\left(\mathrm{Bq} \mathrm{kg}^{-1}\right.$, d.w.). The sediment horizons were carefully separated onboard in $1-\mathrm{cm}$ resolution. Frozen samples were then analysed by highresolution gamma spectrometry, and the concentration of ${ }^{210} \mathrm{~Pb}$ measured in each layer, using the technique described by Cutshall et al. (1983).The vertical profiles are expressed in Bequerels $\mathrm{kg}^{-1}$ dry sediment (x axis) against mass depth $\left(\mathrm{g} \mathrm{cm}^{-2}\right.$ ) (y axis), rather than depth in $\mathrm{cm}$, to overcome artefacts introduced by sediment compaction.

taken in the inner part of Kongsfjorden (Fig. 18), using Niemistö and modified Reineck corers (for details concerning filtration and samples analysis procedures, see Fig. 19 caption). Most of the suspended particles are deposited in the inner fjord area. The first depositional front is in the vicinity of the marginal zone of glaciers. The sediment accumulation rates decrease sharply by about one order of magnitude from the glacier front $\left(20000 \mathrm{~g} \mathrm{~m}^{-2} \mathrm{a}^{-1}\right)$ to the secondary sill in the central part of the fjord (1800 - $\left.3800 \mathrm{~g} \mathrm{~m}^{-2} \mathrm{a}^{-1}\right)$ and, again, by another order of magnitude towards the outer fjord (200 $\mathrm{g} \mathrm{m}^{-2} \mathrm{a}^{-1}$; Fig. 18).

The total inventories of particle-associated contaminants follow the same trend. For instance, ${ }^{137} \mathrm{Cs}$ (an anthropogenic radionuclide introduced into the environment within the last 50 years, which is associated with clay minerals in the coastal environment) is "trapped" in the sediments of the inner fjord, which act as a temporary reservoir of radionuclides. The maximum depth of occurrence of ${ }^{137} \mathrm{Cs}$ in surficial sediments varies from $>60 \mathrm{~cm}$ in the inner fjord to $10 \mathrm{~cm}$ in the central fjord and $<5 \mathrm{~cm}$ in outer areas, a depth 
that is compatible with physical and/or biological activity (Papucci et al. 1998).

To summarize the findings: a) the horizontal and vertical dispersion of suspended matter, both organic and inorganic, shows marked seasonality, mainly in relation to particle export from glaciers. b) The concentration of TSS begins to increase in April, reaching its maximum in July. By mid-September the process is almost completed. c) The residence time of particles in the water column is about 30 days in the whole fjord, except near the glacier front, where the sedimentation processes are very fast. d) A sharp peak of concentration close to the glacier front characterizes the spatial distribution of suspended particles. The area where maximum sedimentation occurs is the zone marginal to the glaciers: $200-400 \mathrm{~m}$ from the glacier front. A regular decrease in TSS concentration from the inner part of the fjord towards the central and outer parts is also observed. e) The vertical distribution of particles is characterized by sub-surface maxima. Close to the glacier it is positioned at $10 \mathrm{~m}$ and is mainly related to flocculation processes where brackish water starts to mix with more saline water (Syvitski 1980); in the central/outer parts of the fjord it is located at $20 \mathrm{~m}$, in connection with the biological activity and the very low sinking velocity of fine inorganic particles. f) The particles exported by the glacier are mainly trapped in the inner part of the fjord, where the sediment accumulation rate is one order of magnitude higher than in the central fjord, and two orders of magnitude higher than in the outer shelf area.

\section{Underwater radiation regime}

\section{General characteristics}

The processes governing the penetration of light into the marine environment are of great importance for the productivity and ecology of marine ecosystems (Hop et al. 2002). The spectral distribution of solar radiation reaching the Earth's surface depends on the radiation emitted by the sun and seasonal variations in the sun-earth separation, the optical properties of the atmosphere, the solar zenith angle and the reflection properties of the earth surface (spectral albedo). Combining scattering and absorption processes, the most important optical properties of the atmosphere are determined by the content of stratospheric ozone, aerosols and water or ice particles (clouds). Scattering and absorption by water molecules govern the inherent properties of the water, as well as dissolved organic matter (DOC), organic particles (e.g. phytoplankton) and inorganic sediments. While the attenuation of solar radiation by chlorophyll and sediments does not show a strong spectral dependence, the content of DOC strongly affects the attenuation of UV in the water column (see e.g. Jerlov 1976; Kirk 1994). However, the content of DOC in seawater is normally low in the Arctic because of low runoff of organic material from the sparse vegetation on land. As mentioned previously, the glaciers transport a large amount of mineral particles to Kongsfjorden, which results in a strong gradient in sediment loading from the glacier to the outer fjord. This content of sediment particles is the main factor controlling both the irradiance of UV and visible light penetrating the water column in Kongsfjorden and, therefore, the extent of the euphotic zone as well as the spectral composition of penetrating radiation.

\section{Influence of suspended particles on the extension of the euphotic zone}

As the increase in concentration of suspended inorganic matter in the surface water results from the seasonal input of turbid freshwater from melting snow and calving glaciers, water turbidity changes drastically in the course of the year. In the beginning of the summer season, meltwater forms a turbid brackish water layer extending about $1 \mathrm{~m}$ above the marine water, strongly decreasing light penetration into the water column of the fjord. Below this brackish water layer, the water body is still clear, but later in summer the sediment-rich water is mixed with the sea water and the water column become turbid down to several metres (Hanelt et al. 2001). Apart from the seasonal variability in water turbidity, there is also a marked gradient in the extent of the euphotic zone along the main fjord axis. In the following, the extent of the euphotic zone is expressed as the $1 \%$ depth of surface irradiance (PAR) and corresponding vertical attenuation coefficients of downward irradiance $\left(\mathrm{K}_{\mathrm{d}}\right.$; see Kirk 1994). Throughout the year, the highest water transparency is found in the mouth of the fjord, where the lower limit of the euphotic zone was determined to be $33.5 \mathrm{~m}$ depth $\left(\mathrm{K}_{\mathrm{d}}=0.13 \mathrm{~m}^{-1}\right.$; 
Keck et al. 1999). At this site, the concentration of suspended particles in the surface layer hardly ever exceeds $15 \mathrm{mg} \mathrm{dm}^{-3}$.

In the central part of the fjord, e.g. in the area between the islands of Lovénøyane, the concentration of suspended particles range from 15 to $50 \mathrm{mg} \mathrm{dm}^{-3}$ and the observed thickness of the euphotic zone varies from 6 to $25 \mathrm{~m}\left(\mathrm{~K}_{\mathrm{d}}=0.76-0.18 \mathrm{~m}^{-1}\right)$ in correlation with the prevailing current direction and the phase of the tide (up- or down-fjord current).

In contrast, in the innermost part of the fjord, where the concentration of suspended mineral particles can be $>340 \mathrm{mg} \mathrm{dm}^{-3}$ close to fluvioglacial outflows, the euphotic zone might be limited to only $0.3 \mathrm{~m}$, resulting in extremely high $K_{d}$ values $\left(K_{d}=15 \mathrm{~m}^{-1}\right)$. Similar large gradients of sediment concentration and attenuation coefficients, with $1 \%$ levels of UV-B and PAR radiation reaching from 4 to $22 \mathrm{~m}$ (for UV-B and PAR, respectively) in outer Kongsfjorden to less than 0.5 (UV-B) to $1 \mathrm{~m}$ (PAR) close to the glacier front have also been observed by Ørbæk et al. (unpubl. data). However, much reduced light intensity ( $0.01 \%$ of surface irradiance) can still be noted under the muddy surface layer close to the glaciers. This phenomenon might be connected with the light transmission through icebergs (M. Zajaczkowski, unpubl. data).

\section{Role of sea ice}

Surface albedo, snow and ice thickness as well as the optical properties of snow and ice control the transmission of light in the sea-ice-snow system (Perovich et al. 1993; Gerland et al. 1999b; Winther et al. 1999; Winther et al. 2001). Gerland et al. (1999a) described these factors from observations in Kongsfjorden during the spring seasons of 1997 and 1998. A decrease in albedo during spring is mainly due to thinning of the snow cover, development of a refrozen snow layer and snow-grain growth from about $2 \mathrm{~mm}$ up to $10 \mathrm{~mm}$ diameter. The sea ice conditions in June (see section on sea ice conditions) further reduce the general surface albedo. Maximum surface reflectance in mid-May 1997 was about 0.96 , whereas in mid-June it was reduced to 0.74 . Since snow that undergoes metamorphosis due to warming usually becomes more transparent to solar radiation (Gerland et al. 2000; Winther et al. 2002), both thinning and changes of snow properties increase the level of solar radiation in the water column below the sea ice. In an experiment measuring under-ice irradiance, both with snow on top of the sea ice and also when the snow was removed from the ice, Gerland et al. (1999a) showed that about $1 \%$ of the surface value of radiation (wavelength of $550 \mathrm{~nm}$ ) penetrated to the water when it was covered by sea ice and snow. Removal of the $20 \mathrm{~cm}$ thick snow cover, resulted in a 27 -fold increase in irradiance penetrating the sea ice. Qualitative thick section analysis on ice cores from the same study revealed large variations in optical properties with depth, depending on ice texture, amount of air bubbles, brine pockets and channels, and the content of ice algae. The latter were found in the second half of May, giving the ice a light brownish colour in the bottom part of the ice (Gerland et al. 1999a; Hop et al. 2002).

Wiktor (1999) measured the extent of the euphotic zone with respect to different sea ice conditions. While in the inner part of the fjord, under $1.1 \mathrm{~m}$ thick first-year ice topped by a 0.26 $\mathrm{m}$ snow cover, the extent of the euphotic zone was $1.4 \mathrm{~m}$, it increased to 14 or $24 \mathrm{~m}$ under $0.3 \mathrm{~m}$ greywhite ice topped by $0.01 \mathrm{~m}$ snow or $0.06 \mathrm{~m}$ of thin fast ice (nilas), respectively. Under open pack ice conditions, the euphotic zone may extend down to $25 \mathrm{~m}$ depth (Wiktor 1999).

\section{$U V$ radiation in the water column}

In the context of seasonal ozone depletion over the polar regions of the Northern and Southern hemispheres and the consequent increase of solar UV-B (280 - $320 \mathrm{~nm})$ reaching the Earth's surface, monitoring of underwater UV radiation is of high ecological importance. The biological effects of present day UV-B levels as well as the probable consequences of future ozone depletion on Arctic ecosystems are reviewed in detail in Hessen (2002). Studies conducted in Kongsfjorden have shown that UV radiation might confer strong negative effects on the marine environment (Hop et al. 2002). Despite the high relevance of continuous UV-B measurements inside the water column of Kongsfjorden, the database is still very limited. To date, two data sets are available from the years 1997-98, recorded by an underwater 32 channel UV-B spectroradiometer developed at the Alfred Wegener Institute (see Bischof et al. 1998; Hanelt et al. 2001) installed on the Ny- 
Fig. 20. Seasonal variation of the averaged vertical attenuation coefficient $\left(\mathrm{K}_{\mathrm{d}}\right)$ of downward UV-B radiation (open symbols) and corresponding $1 \%$ depths (filled symbols), calculated from spectrora-diometrical measurements in a depth range from $0-6 \mathrm{~m}$ from the Ny-Ålesund jetty during the summer seasons 1997 (circles) and 1998 (triangles).

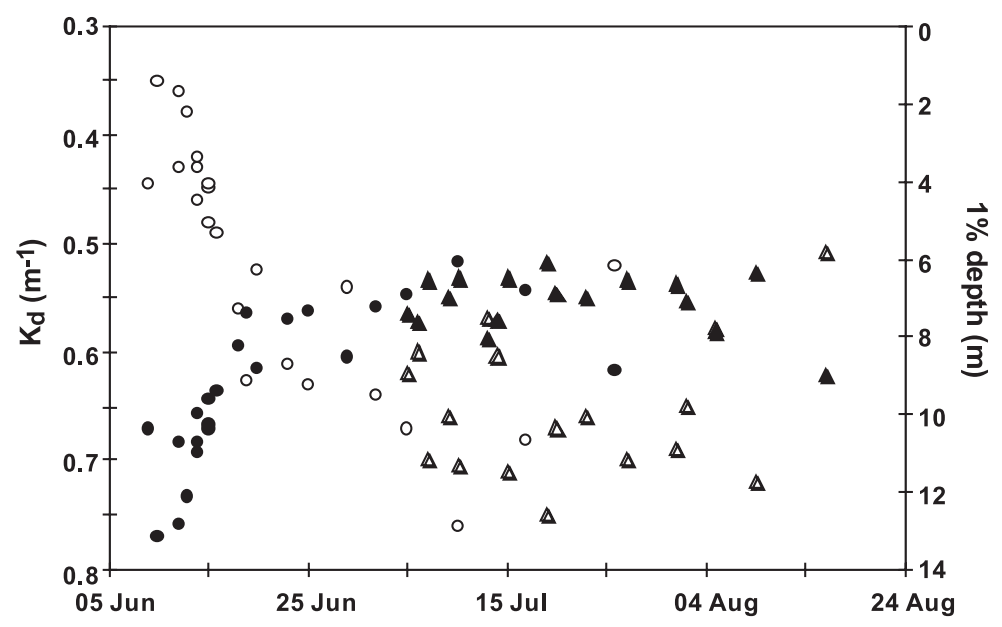

Ålesund jetty. Continuous measurements during the summer seasons demonstrate the strong seasonal variability in UV-B penetration of the Kongsfjorden water column (Fig. 20). Vertical attenuation coefficients of downward UV-B were averaged from 1 to $6 \mathrm{~m}$ water depth and reveal the decreasing UV-B transparency due to the input of turbid meltwater during the transition from spring to summer. Under conditions of high water transparency, UV-B radiation penetrates the water column of Kongsfjorden down to a $1 \%$ depth of $13 \mathrm{~m}$ (Fig. 20). From the middle of June, UV-B transparency decreases strongly due to the input of turbid meltwater. Whereas UV-B irradiance decreases by about $22 \% \mathrm{~m}^{-1}$ in clear waters during spring, the attenuation increases to about $53 \% \mathrm{~m}^{-1}$ during summer.

By calculating $\mathrm{K}_{d}$ values of UV-B for different depth intervals separately, the stratification of the water column can be confirmed (Hanelt et al. 2001). While UV-B transparency in the first $3 \mathrm{~m}$ water depth decreased markedly in the course of the season, $\mathrm{K}_{\mathrm{d}}$ values of water masses deeper than $4 \mathrm{~m}$ depth did not change much and were relatively low $\left(\mathrm{K}_{\mathrm{d}} \leq 0.5 \mathrm{~m}^{-1}\right)$ during the spring/ summer season of 1998 .

The biological significance of seasonal changes in UV-B transparency, in addition to the daily variations in surface irradiance, is illustrated by data obtained from biological UV dosimeters which were installed at the water surface and in different water depths inside Kongsfjorden off Jakobskjelda, Blomstrandhalvøya (Aguilera et al. 1999). These dosimeters consist of UVsensitive monolayers of Bacillus subtilis spores.
Germinability of spores after exposure reflects UV induced DNA damage, and data are expressed as the minimal erythemal dose (MED) per day (Quintern et al. 1992; Furusawa et al. 1998). Dosimeters exposed at $1 \mathrm{~m}$ water depth from 22-29 June 1998 recorded $16 \%$ of the daily MED in air, whereas $7 \%$ was measured at $3 \mathrm{~m}$ depth. In contrast, dosimeters exposed from 15-23 July 1998 in $1 \mathrm{~m}$ water depth only recorded $10 \%$ of the daily mean MED measured in air, and at $3 \mathrm{~m}$ only $2 \%$ was detected (Hanelt et al. 2001).

\section{Summary and concluding remarks}

This paper has attempted to demonstrate for Kongsfjorden-Krossfjorden that understanding the complex interactions between the processes which determine the circulation and exchange demands a thorough knowledge of the forces which govern these processes: wind, freshwater discharge, tide, and ice formation and melting. Moreover, interpretation of data pertaining to suspended particulate matter and sedimentation processes is dependent on detailed information about circulation patterns.

It has been shown that the main driving forces within the Kongsfjorden-Krossfjorden system have a pronounced seasonal pattern of variation. For the freshwater supply, this is related to variations in the calving rate of the glaciers, precipitation and melting or freezing due to the seasonal variation in air temperature. The seasonal variation of the strength of the katabatic winds is also strongly related to the air temperature. The 
exchange with the adjacent shelf is shown to be related to irreversible exchange across the front between the AW along the shelf slope and the ArW on the shelf. Most of the exchanged water crosses the shelf and numerous intrusions to the fjord system take place every year.

We conclude that the main forces driving circulation and the transfer mechanisms have been identified and that the variations of the circulation pattern within the KongsfjordenKrossfjorden system, the variation pattern of the driving forces, and the effect of the coastal regime on the fjords are known in their broad outlines. However, as for fjords in general, there is a considerable gap in our knowledge concerning quantification of the effects of, and interaction between, each of the individual forces on the flow field and also with the ice conditions and fluxes of particulate matter:

a) It has been demonstrated that when a low pressure cell is located south-west of Svalbard there is a coupling between the geostrophic and the near surface wind regime, which enhances the katabatic flow (fjord wind). However, it is not known how sensitive the wind conditions in the fjord system are to movements of the low pressures. Moreover, it is not known how the geostrophic wind regime affects Krossfjorden and thus the interaction between the fjord arms. Future investigations should therefore also include measurement of meteorological time series (wind, air temperature) from Krossfjorden.

b) An estimation of the total run-off per year from different sources has been offered. The estimations are, however, burdened with some uncertainty. More detailed information about the different sources is necessary, especially about the mass balance of the large glacier Kronebreen at the head of Kongsfjorden and the glacier Lilliehöökbreen in the western ramification at the head of Krossfjorden. The total annual runoff is not a suitable basis for distinguishing the effects of the run-off and other driving forces on the observed circulation. This requires a quantification of the seasonal variation of the supply from the different sources. There is no information about the hydrographic conditions in the fjord system between late autumn and early spring. Before such data are available the only way to obtain such information is by modelling, which requires data about the seasonal run-off.

c) There is a great need for more systematic monitoring of the sea ice conditions in the fjord system, e.g. using radar remote sensing. Besides surface cooling, brine release during ice formation is a main reason for the homogenization of the water masses which takes place in the inner part of Kongsfjorden (zones 3 and 4 in Fig. $1 \mathrm{~b}$ in Hop et al. 2002) during the winter. However, this important part of the fjord dynamics has never been investigated and will be given preference in the field investigations in the coming winter seasons.

d) Flux estimates based on measurements of concentrations (C) and velocity field (u), i.e. $<\mathrm{uC}>$, are uncertain due to the lack of a comprehensive array of instrumentation necessary to get reliable values. Field experiments combined with application of model tools have been used to investigate the circulation of the upper layer in the fjord system and some knowledge about conditions in the upper layer in the summer and autumn has been acquired. From observed hydrographic sections, we also have indications that an active exchange between the fjords and the adjacent shelf takes place. The existing data, however, do not form a base for thorough investigations of the mechanisms controlling the exchange or for estimation of fluxes.

To fill the lacunae identified above, there is a need for more research into physical processes on different temporal and spatial scales in the fjord system and the adjacent shelf regime, with special focus on seasonal variations. There is also a need to determine the effect of the complex topography of the fjord system on horizontal pressure gradients, which may counteract the rotational dynamics. Furthermore, there is a great need to distinguish the water mass exchange which is wind-driven (up/down welling at the coast) from that which is related to ageostrophic processes in the slope current. Future investigations should therefore comprise the whole water column in the gradient from the head of the fjord arms to the shelf, including the shelf slope.

Powerful tools to study the dynamics described above are numerical models and a coupled 3-D fjord-shelf model is currently being prepared. Based on this model, in combination with field experiments, efforts will be made to elucidate and quantify the dynamic processes that are currently only partly understood.

e) The concentration of total suspended solids and the sediment accumulation rate has been shown to be one order of magnitude higher in front of the tidal glaciers than in the central fjord, 
and two orders of magnitude higher than in the outer shelf area. This is related to the strong mixing processes near the glaciers compared to a strong stratification of the water column beyond this area. Future investigations should aim at filling the major gaps of knowledge that have been identified. These include processes occurring at the interface between glaciers and sea, freshwater outputs, seasonality of particle population, scavenging, and sediment accumulation/remobilization processes, coupling with hydrological data. Other significant gaps include stability of bottom sediments and their mobility with time, and seasonal variability of particle fluxes in the whole fjord system (TSS, PIM and POC).

f) It has been shown that suspended particles and sea ice strongly affect the radiation regime in the inner part of Kongsfjorden. During the icefree season, the influence of suspended particles on the extent of the euphotic zone is substantial. It may limit the extension of the euphotic zone to $0.3 \mathrm{~m}$ in the innermost part of the fjord, while in the central and outer parts it varies from $6 \mathrm{~m}$ to $30 \mathrm{~m}$. Almost all investigations of the radiation regime in the fjord system have been carried out in Kongsfjorden, whereas the radiation regime in Krossfjorden is largely unknown. There is a close relation between the distribution of suspended particles and the circulation pattern. The circulation pattern shows a strong interaction between the fjord arms and marked cross-fjord gradients and future investigations should therefore be carried out in the whole fjord system.

g) The biological significance of seasonal changes in UV-B transparency and daily variations in surface irradiance have been investigated. However, the database is still too sparse to predict the ecological impact of UV-B on the Kongsfjorden ecosystem (Hop et al. 2002) in the context of ozone depletion, and more UV$\mathrm{B}$ measurements inside the water column of the fjord system are needed.

Acknowledgements.-The Kongsfjord Ecosystem Workshop 2000, where this paper was conceived, was financially supported by the Research Council of Norway (project no. 135644/700), the Norwegian Ministry of Environment, Kings Bay AS, University Courses on Svalbard, the Large Scale Facility/EU TMR Programme, and the Norwegian Polar Institute. The workshop included 40 participants from France, Germany, Italy, Norway, Poland, Russia, Spain, Sweden and the UK. We thank Haakon Hop and Ingrid Storhaug
(Norwegian Polar Institute) for help in the preparation of the manuscript; Anne Estoppey and Harald Faste Aas (Norwegian Polar Institute) and Frank Cleveland (GIUB) for preparation of some of the figures; and Else Nøst Hegseth (Norwegian College of Fishery Science, University of Tromsø) for valuable comments on the first draft. We also thank Gurdeep Stephens (soprano, Canada) and Michael Greenacre (guitar/ piano, University of Pompeu Fabra, Spain) whose memorable evening concert gave the workshop an extra something.

\section{References}

Aagaard, K., Foldvik, A. \& Hillman, S. R. 1987: The West Spitsbergen Current: disposition and water mass transformation. J. Geophys. Res. 92, 3778-3784.

Aguilera, J., Karsten, U., Lippert, H., Vögele, B., Philipp, E., Hanelt, D. \& Wiencke, C. 1999: Effects of solar radiation on growth, photosynthesis and respiration of marine macroalgae from the Arctic. Mar. Ecol. Prog. Ser. 191, 109-119.

Argentini, S., Viola, A., Mastrantonio, G., Maurizi, G., Giorgiadis, T. \& Nardino, M. 2000: Dynamics of the atmospheric boundary layer at $\mathrm{Ny}$-Ålesund. In $\mathrm{M}$. Colacino \& G. Giovanelli (eds): 8th Workshop Italian Research on Antarctic Atmosphere. Societa Italiana di Fisica Conference Proceedings 69, 175-185. Italian Physical Society

Asplin, L. 1995: Examination of local circulation in a wide, stratified fjord including exchange of water with the adjacent ocean, due to constant local up-fjord wind. In H. R. Skjoldal et al. (eds.): Ecology of fjords and coastal waters. Pp. 177-184. Amsterdam: Elsevier.

Asplin, L., Salvanes, A. G. V. \& Kristoffersen, J. B. 1999: Non-local wind-driven fjord-coast advection and its potential effect on pelagic organisms and fish recruitment. Fish. Oceanogr. 8, 255-263.

Bergh, S. G., Maher, H. D. \& Braathen, A. 2000: Tertiary divergent thrust directions from partitioned transpression, Brøggerhalvøya, Spitsbergen. Nor. Geol. Tidsskr. 80, 63-82.

Bergström, S. 1972: Utveckling och tillëmpning av en digital avrinningsmodell. (Development and application of a digital run-off model.) SMHI Rep. Hydrol. 22. Norrköping: Swedish Meteorological and Hydrological Institute.

Beszczyeska-Møller, A., Weslawski, J. M., Walczowski, W. \& Zajaczkowski, M. 1997: Estimation of glacial meltwater discharge into Svalbard coastal waters. Oceanologia 39, 289-298.

Bischof, K., Hanelt, D., Tüg, H., Karsten, U., Brouwer, P. E. M. \& Wiencke, C. 1998: Acclimation of brown algal photosynthesis to ultraviolet radiation in Arctic coastal waters (Spitsbergen, Norway). Polar Biol. 12, 388-395.

Bischof, K., Hanelt, D. \& Wiencke, C. 1999: Acclimation of maximal quantum yield of photosynthesis in the brown alga Alaria esculenta under high light and UV radiation. Plant Biol. 1, 435-444.

Björnsson, H., Gjessing, Y., Hamran, S. E., Hagen, J. O., Liestøl, O., Pálsson, F. \& Erlingsson, B. 1996: Temperature regime of sub-polar glaciers mapped by multi-frequency radio-echo sounding. J. Glaciol. 42, 23-32.

Blumberg, A. F. \& Mellor, G. L. 1987: A description of a three-dimensional coastal ocean circulation model. In N. Heaps (ed.): Three-dimensional coastal ocean models. Pp. 1-16. Washington D.C.: American Geophysical Union. 
Blümel, W. 1971: Kleinkarst und Formen selektiver Erosion auf der Blomstrandhalvøya/NW Spitzbergen. (Karst and erosion forms on Blomstrandhalvøya/NW Spitsbergen.) Der Aufschluss 22, 149-163.

Brown, R. D. \& Cote, P. 1992: Interannual variability of landfast ice thickness in the Canadian high Arctic, 1950-89. Arctic 45, 273-284.

Bruland, O. \& Sand, K. 1994: The Nordic HBV-model applied to an Arctic watershed. Proceedings of the Tenth International Northern Research Basins Symposium and Workshop, Spitsbergen, Norway. SINTEF Rep. STF22 A96415, 594-608. Foundation for Scientific and Industrial Research, Norwegian Institute of Technology.

Cannon, G. A. \& Holbrook, J. R. 1981: Wind-induced seasonal interaction between coastal and fjord circulaton. In R. Sætre \& M. Mork (eds.): The Norwegian Coastal Current. Vol. 1. Pp. 131-151. University of Bergen.

Cochran, J. K., Barnes, C., Achma, D., Hirshberg, D. J. 1995: Thorium-234/Uranium-238 disequilibrium as an indicator of scavenging rates and particulate organic carbon fluxes in the Northeast Water Polynya, Swerland. J. Geophys. Res. 100(C3), 4399-4410.

Cushman-Roisin, B., Asplin, L. \& Svendsen, H. 1994: Upwelling in broad fjords. Cont. Shelf Res. 14, 1701-1721.

Cutshall, N. H., Lowsen, I. L., Olsen, C. R. 1983: Direct analysis of ${ }^{210} \mathrm{~Pb}$ in sediment samples: self-absorption corrections. Nucl. Instruments Methods 206, 309-312.

Dean, W. E. Jr. 1974: Determination of carbonate and organic matter in calcareous sediments and sedimentary rocks by loss on ignition: comparison with other methods. $J$. Sediment. Petrol. 44, 242-248.

Domack, E. W. \& Ishman, S. 1993: Oceanographic and physiographic controls on modern sedimentation within Antarctic fjords. Geol. Soc. Am. Bull. 105, 1175-1189.

Dowdeswell, J. A. \& Forsberg, C. F. 1992: The size and frequency of icebergs and bergy bits derived from tidewater glaciers in Kongsfjorden, northwest Spitsbergen. Polar Res. 11, 81-91.

Dyer, K. R. 1989: Sediment processes in estuaries: future research requirements. J. Geophys. Res. 94(C10), 1432714339.

Eicken, H. 1992: Salinity profiles of Antarctic sea ice: field data and model results. J. Geophys. Res. 97(C11), 1554515557.

Eilertsen, H. C., Taasen J. P. \& Weslawski J. M. 1989: Phytoplankton studies in the fjords of west Spitsbergen: physical environment and production in spring and summer. J. Plankton Res. 11, 1245-1260.

Eisma, D. 1986: Flocculation and deflocculation of suspended matter in estuaries. Neth. J. Sea Res. 20, 183-199.

Elverhøi, A., Liestøl, O. \& Nagy, J. 1980: Glacial erosion, sedimentation and microfauna in the inner part of Kongsfjorden, Spitsbergen. Geological and geophysical research in Svalbard and on Jan Mayen, 1980. Nor. Polarinst. Skr. 172, 33-61. Oslo: Norwegian Polar Institute.

Elverhøi, A., Lønne, O. \& Seland R. 1983: Glaciomarine sedimentation in modern fjord environment, Spitsbergen. Polar Res. 1, 127-149.

Farmer, D. \& Freeland, H. J. 1983: The physical oceanography of fjords. In M. V. Angel \& J. J. O’Brien (eds): Prog. Oceanogr. 12, 147-220. Oxford: Pergamon Press.

Flemming, K. M., Dowdeswell, J. A. \& Orlemans, J. 1997: Modelling the mass balance of northwest Spitsbergen glaciers and response to climate change. Ann. Glaciol. 24, 203-210.
Førland E. J., Hansen-Bauer, I. \& Nordli, P. Ø. 1997: Orographic precipitation at the glacier Austre Broggerbreen. DNMI Rep. 2/97 Klima. Oslo: Norwegian Meteorological Institute.

Forman, S. L. \& Miller, G. H. 1984: Time-dependent soil morphologies and pedogenic processes on raised beaches, Brøggerhalvøya, Spitsbergen, Svalbard Archipelago. Arct. Alp. Res. 16, 381-394.

Furusawa, Y., Quintern, L. E., Holtschmidt, H., Koepke, P. \& Saito, M. 1998: Determination of the erythemaeffective solar radiation in Japan and Germany with a spore monolayer film optimised for the detection of UVB and UVA-results of a field campaign. Appl. Microbiol. Biotechnol. 50, 597-603.

Gade, H. G. 1970: Hydrographic investigations in the Oslofjord, a study of water circulation and exchange processes. Rep. 24. Geophysical Institute, University of Bergen.

Gascard, J. C., Richez, C. \& Rouault, C. 1995: New insights on large-scale oceanography in Fram Strait: the Spitsbergen Current. Coast. Estuar. Stud. 49, 131-182.

Gerland, S., Liston, G. E., Winther, J.-G., Ørbæk, J. B. \& Ivanov, B. 2000: Attenuation of solar radiation in Arctic snow: field observations and modelling. Ann. Glaciol. 31, 364-368.

Gerland, S. \& Winther, J.-G. 2000: Development of thickness and temperature of first-year fast ice in an Arctic fjord. Abstract. Suppl. to Eos Trans. AGU 81, 760.

Gerland, S., Winther, J.-G., Ørbæk, J. B. \& Ivanov, B. V. 1999a: Physical properties, spectral reflectance and thickness development of first year fast ice in Kongsfjorden, Svalbard. Polar Res. 18, 275-282.

Gerland, S., Winther, J.-G., Ørbæk, J. B., Liston, G. E., Øritsland, N. A., Blanco, A. \& Ivanov, B. 1999b: Physical and optical properties of snow covering Arctic tundra on Svalbard. Hydrol. Proc. 13, 2331-2343.

Gjevik, B. \& Straume, T. 1989: Model simulations of the $\mathrm{M}_{2}$ and the $\mathrm{K}_{1}$ tide in the Nordic seas and the Arctic Ocean. Tellus 41A, 73-96.

Goldberg, E. D. 1963: Geochronology with ${ }^{210} \mathrm{~Pb}$. In: Radioactive dating. STI/PUB/68. Pp. 121-131. Vienna: International Atomic Energy Agency.

Gonzalez, H. E., Gonzalez, S. R. \& Brummer, G. J. A. 1994: Short-term sedimentation pattern of zooplankton, faeces and microplankton at a permanent station in the Bornafjorden (Norway) during April-May 1992. Mar. Ecol. Prog. Ser. 105, 31-45.

Görlich, K., Weslawski, J. M. \& Zajaczkowski, M. 1987: Suspension settling effect on macrobenthos biomass distribution in the Hornsund fjord, Spitsbergen. Polar Res. $5,175-192$.

Greisman P. 1979: On upwelling driven by the melt of ice shelves and tidewater glaciers. Deep-Sea Res. 26A, 10511065.

Groß, C., Tüg, H. \& Schrems, O. 2001: Three years of spectral resolved UV-measurements at Koldewey Station (1997-1999). Mem. Natl. Inst. Polar Res., Spec. Issue 54, 113-123.

Hadges, J. I. \& Stern, J. H. 1984: Carbon and nitrogen determinations of carbonate containing solids. Limnol. Oceanogr. 29, 657-663.

Hagen, J. O. \& Lefauconnier, B. 1995: Reconstructed run-off from the high Arctic basin Bayelva in Svalbard based on mass balance measurements. Nord. Hydrol. 26, 285-296.

Hagen, J. O. \& Liestøl, O. 1990: Long term glacier mass balance investigations in Svalbard 1950-1988. Ann. 
Glaciol. 14, 102-106.

Haldal, P. \& Haldal, K. 1973: Phytoplankton, chlorophyll and submarine light condition in Kings Bay, Spitsbergen, July 1971. Norw. J. Bot. 20, 99-108.

Hanelt, D., Tüg, H., Bischof, K., Groß, C., Lippert, H., Sawall, T. \& Wiencke, C. 2001: Light regime in an Arctic fiord: a study related to stratospheric ozone depletion as a basis for determination of UV effects on algal growth. Mar. Biol. 138, 649-658.

Hansen-Bauer, I., Kristensen Solås, M. \& Steffensen, E. L. 1990: The climate of Spitsbergen. DNMI Rep. 39/90 Klima. Oslo: Norwegian Meteorological Institute.

Hartmann, J., Albers, F., Argentini, S., Bochert, A., Bonafè, U., Cohrs, W., Conidi, A., Reese, D., Georgiadis, T., Ippoliti, A., Kaleschke, L., Lupkes, C., Maixner, U., Mastrantonio, G., Ravegnani, F., Reuter, A., Trivellone, G. \& Viola, A. 1999: Arctic Radiation and Turbulence Interaction Study (ARTIST). Report on Polar Research 305/99. Bremerhaven: Alfred Wegener Institute for Polar and Marine Research.

Hessen, D. O. (ed.) 2002: UV radiation and Arctic ecosystems. Berlin: Springer.

Hjelle, A., Piepjohn, K., Saalmann, K., Ohta, Y., Thiedig, F., Salvigsen, O. \& Dallmann, W. K. 1999: Geological map of Svalbard 1:100,000, sheet A7G Kongsfjorden. Nor. Polarinst. Temakart 30. (Map and explanatory text.) Tromsø: Norwegian Polar Institute.

Hop, H., Pearson, T., Hegseth, E. N., Kovacs, K. M., Weslawski, J. M., Wiencke, C., Kwasniewski, S., Eiane, K., Leakey, R., Cochrane, S., Zajaczkowski, M., Lønne, O. J., Mehlum, F., Lydersen, C., Gulliksen, B., Falk-Petersen, S., Poltermann, M., Wängberg, S.-Å., Kendall, M., Bischof, K., Y., Voronkov, A., Kovaltchouk, N. A., Gabrielsen, G. W., Wlodarska-Kowalczuk, M., Wiktor, J., di Prisco, G., Estoppey, A., Papucci, C. \& Gerland, S. 2002: The marine ecosystem of Kongsfjorden, Svalbard. Polar Res. 21, 167208 (this issue).

Hopkins, T. S. 1991: The GIN Sea-a synthesis of its physical oceanography and literature review 1972-1985. Earth Sci. Rev. 30, 175-318.

Ingvaldsen, R., Bø-Reitan, M., Svendsen, H. \& Asplin, L. 2001: The upper layer circulation in Kongsfjorden and Krossfjorden-a complex fjord system on the west coast of Spitsbergen. Environmental Research in the Arctic 2000: Proceedings of the Second International Symposium on Environmental Research in the Arctic and Fifth NyAlesund Scientific Seminar, 23-25 February 2000. Mem. Natl. Inst. Polar Res., Spec. Issue 54, 393-407. Tokyo: National Institute of Polar Research.

Ito, H. \& Kudoh, S. 1997: Characteristics of water in Kongsfjorden, Svalbard. Proc. NIPR Symp. Polar Meteorol. Glaciol. 11, 211-232. Tokyo: National Institute of Polar Research.

Jerlov, N. G. 1976: Marine optics. Amsterdam: Elsevier.

Kasajima, Y. \& Svendsen, H. in press: Tidal features in the Fram Strait. Cont. Shelf. Res.

Keck, A. 1999: West Spitsbergen fjords (Svalbard, Norwegian Arctic): physical settling and sedimentation. In A. $\mathrm{S}$. Heriskanen et al. (eds.): Sedimentation and recycling in aquatic ecosystems - the impact of pelagic processes and planktonic food web structure. Finn. Environ. 263, 58-68.

Keck, A., Wiktor, J., Hapter, R. \& Nilsen, R. 1999: Plankton assemblages related to physical gradients in an Arctic, glacier-fed fjord in summer. ICES J. Mar. Sci. 56, 203214.

Kirk, J. T. O. 1994: Light and photosynthesis in aquatic ecosystems. Cambridge: Cambridge University Press.

Klinck, J. M., O’Brien, J. J. \& Svendsen, H. 1981: A simple model of fjord and coastal circulation interaction. J. Phys. Oceanogr. 11, 1612-1626.

Koide, M., Bruland, K. W. \& Goldberg, E. D. 1973: Th-238/ Th-232 and $\mathrm{Pb}-210$ geochronologies in marine and lakes sediments. Geochim. Cosmochim. Acta 37, 1171-1187.

König-Langlo, G. \& Marx, B. 1997: The meteorological information system at the Alfred-Wegener Institute. In M. Lautenschlager and M. Reinke (eds.): Climate and environmental database systems. Pp. 117-126. Dordrecht: Kluwer Academic Press.

Langone, L., Frignani, M., Cochran, J. K. \& Ravaioli, M. 1997: Scavenging processes and export fluxes close to a retreating seasonal ice margin (Ross Sea, Antarctic). Water Air Soil Pollut. 99, 705-715.

Lefauconnier, B. 1987: Fluctuations glaciaires dans le Kongsfjord (Baie du Roi), $79^{\circ} N$, Spitsbergen, Svalbard. Analyse et consequence. (Fluctuations in the glaciers of Kongsfjorden, $79^{\circ} \mathrm{N}$, Spitsbergen, Svalbard. Analysis and consequences.) Ph.D. thesis. Université de Grenoble.

Lefauconnier, B. \& Hagen, J. O. 1991: Surging and calving glaciers in eastern Svalbard. Nor. Polarinst. Medd. 116. Oslo: Norwegian Polar Institute.

Lefauconnier, B., Hagen, J. O. \& Rudant, J. P. 1994: Flow speed and calving rate of Kongsbreen glacier using SPOT images. In S. Spjelkavik (ed.): Proceedings of the Second Circumpolar Symposium on Remote Sensing of Arctic Environments, Tromsø, 4-6 May, 1992. Polar Res. 13, 59-65.

Lefauconnier, B., Hagen, J. O., Ørbæk, J. B., Melvold, K. \& Isaksson, E. 1999: Glacier balance trends in the Kongsfjorden area, western Spitsbergen, Svalbard, in relation to the climate. Polar Res. 18, 307-313.

Lefauconnier, B., Massonnet, D. \& Anker, G. 2001: Determination of ice flow velocity in Svalbard from ERS1 interferometric observations. Environmental Research in the Arctic 2000: Proceedings of the Second International Symposium on Environmental Research in the Arctic and Fifth Ny-Alesund Scientific Seminar, 23-25 February 2000. Mem. Natl. Inst. Polar Res., Spec. Issue 54, 279-290. Tokyo: National Institute of Polar Research.

Lefauconnier, B., Vallon, M., Dowdeswell, J., Hagen, J. O., Pinglot, J. F. \& Pourchet, M. 1993: Global balance of Spitsbergen ice mass and prediction of its change due to climatic change. In I. Troen (ed): Symposium Global Change and Climate Change Impacts, Focusing on European Research. Copenhagen, 6-10 September 1993: EPOCH 0035 Scientific Report. European Programme on Climatology and Natural Hazards.

Liestøl, O. 1976: Pingos, springs and permafrost in Spitsbergen. Nor. Polarinst. Arb. 1975, 7-29.

Liestø1, O. 1980: Permafrost conditions in Spitsbergen. Frost $i$ Jord 21, 23-28.

Liestø1, O. 1988: The glaciers in the Kongsfjorden area, Spitsbergen. Nor. Geogr. Tidsskr. 42, 231-238.

Lydersen, C. \& Gjertz, I. 1986: Studies of the ringed seal (Phoca hispida Schreber 1775) in its breeding habitat in Kongsfjorden, Svalbard. Polar Res. 4, 57-63.

Matthews, J. B. 1981: The seasonal circulation of the Glacier Bay, Alaska fjord system. Estuar. Coast. Shelf Sci. 12, 679700 .

Matthews, J. B. \& Quinlan, A. V. 1975: Seasonal characteristics of water masses in Muir Inlet, a fjord with tidewater glaciers. J. Fish. Res. Board Can. 32, 1693-1703. 
Mehlum, F. 1991: Breeding population size of the common eider Somateria mollissima in Kongsfjorden, Svalbard, 1981-1987. In F. Mehlum (ed.): Eider studies in Svalbard, Oslo 1991. Nor. Polarinst. Skr. 195, 21-29. Oslo: Norwegian Polar Institute.

Melvold, K. \& Hagen, J. O. 1998: Evolution of, a surge-type glacier in its quiescent phase: Kongsvegen, Spitsbergen, 1964-1995. J. Glaciol. 44, 394-404.

Miller, G. H., Sejrup, H.-P., Lehman, S. J. \& Forman, S. L. 1989: Late Quaternary glacial history and marine environmental change, western Spitsbergen, Svalbard Archipelago. Boreas 18, 273-296.

Ørbæk, J. B., Hisdal, V. \& Svaasand, L. E. 1999: Radiation climate variability in Svalbard: surface and satellite observations. Polar Res. 18, 127-134.

Papucci, C., Delfanti, R. \& Mordeglia, B. 1998: Radionuclides as tracers of particle dynamics in the W-Svalbard marine environment. In R. Casacchia et al. (eds.): The Arctic and global change. Multidisciplinary and international efforts at Ny-Alesund: proceedings from the Fourth Ny-Alesund Seminar, Ravello, Italy, 5-6 March 1998. Ny-Alesund Science Managers Committee Publ. 007, 185-192. Rome: Italian National Research Council.

Papucci, C., Delfanti, R. \& Torricelli, L. 1999: Scavenging and sedimentation processes in the marine environment of the Svalbard islands. Extended abstracts: the 4th International Conference on Radioactivity in the Arctic, Edinburgh 1999. Pp. 70-74. Østerås: Norwegian Radiation Protection Authority.

Perovich, D. K., Cota, C. F., Maykut, G. A. \& Grefell, T. C. 1993: Bio-optical observations of first-year Arctic sea ice. Geophys. Res. Lett. 20, 1059-1062.

Pickard, G. L. 1961: Oceanographic features of inlets in the British Columbia mainland coast. J. Fish. Res. Board Can. 16, 907-999.

Piechura, J. 1996: Dense bottom waters in Storfjorden and Storfjordrenna. Oceanologia 38, 285-292.

Proeh1, J. A. \& Rattray, M. Jr. 1984: Low-frequency response of wide deep estuaries to non-local atmospheric forcing. $J$. Phys. Oceanogr. 14, 904-921.

Quadfasel, D., Rudels, B. \& Kurz, K. 1988: Outflow of dense water from a Svalbard fjord into the Fram Strait. Deep-Sea Res. 35, 1143-1150.

Quintern, L. E., Horneck, G., Eschweiler, U. \& Bücker, H. 1992: A biolfilm used as ultraviolet-dosimeter. Photochem. Photobiol. 63, 74-78.

Saloranta, T. M. \& Svendsen, H. 2001: Across the Arctic front west of Spitsbergen: high-resolution CTD sections from 1998-2000. Polar Res. 20, 174-184.

Sexton D. J., Dowdeswell J. A., Solheim A. \& Elverhoi, A. 1992: Seismic architecture and sedimentation in northwest Spitsbergen fjords. Mar. Geol. 103, 53-68.

Sollid, J. L. \& Sørbel, L. 1992: Rock glaciers in Svalbard and Norway. Permafrost Periglacial Process. 3, 215-220.

Steffen, K. 1986: Atlas of the sea ice types-deformation processes and openings in the ice. Zürcher Geographische Schriften 20.

Stigebrandt, A. 1976: Vertical diffusion driven by internal waves in a sill fjord. J. Phys. Oceanogr. 7, 118-122.

Stigebrandt, A. 1990: On the response of the horizontal mean vertical density distribution in a fjord to low-frequency density fluctuations in the coastal water. Tellus 42A, 605-614.

Svendsen, H. 1969: Vindeffect $i$ fjorder. (Wind effects in fjords.) Master's thesis. Geophysical Institute, University of Bergen.

Svendsen, H. 1977: A study of the circulation in a sill fjord on the west coast of Norway. Mar. Sci. Commun. 3, 151-209.

Svendsen, H. 1981: A study of circulation and exchange processes in the Ryfylkefjords. Ph.D. thesis. Geophysical Institute, University of Bergen.

Svendsen, H. 1995: Physical oceanography of coupled fjordcoast systems in northern Norway with special focus on frontal dynamics and tides. In H. R. Skjoldal et al. (eds): Ecology of fjords and coastal waters. Pp. 149-164. Amsterdam: Elsevier.

Swift, J. H. 1986: The Arctic waters. In B. G. Hurdle (ed.): The Nordic seas. Pp. 124-153. New York: Springer.

Syvitski, J. P. M. 1980: Flocculation, aggregation and zooplankton pelletization of sampled sediment in a fjord receiving glacial meltwater. In Freeland et al. (eds.): Fjord oceanography. Pp. 615-623. New York. Plenum Publ.

Vinje, T. 1982: Frequency distribution of sea ice in the Greenland and Barents seas, 1971-80. Nor. Polarinst. Arb. 1980, 57-61. Oslo: Norwegian Polar Institute.

Vinje, T. 2001: Anomalies and trends of sea-ice extent and atmospheric circulation in the Nordic seas during the period 1864-1998. J. Clim. 14, 255-267.

Wassmann, P. 1985: Sedimentation of particulate material in Nordåsvannet, a hypertrophic, land-locked fjord in western Norway. Mar. Ecol. Prog. Ser. 22, 259-271.

Weslawski, J. M., Kwasniewski, S., Wiktor, J. \& Zajaczkowski, M. 1993: Observations on the fast ice biota in the fjords of Spitsbergen. Pol. Polar Res. 14, 331-343.

Weslawski, J. M. \& Legezynska, J. 1998: Glaciers caused zooplankton mortality? J. Plankton Res. 20, 1233-1240.

Whittington, R. J., Forsberg, C. F. \& Dowdeswell, J. A. 1997: Seismic and side-scan sonar investigations of recent sedimentation in an ice-proximal glacimarine setting, Kongsfjorden, north-west Spitsbergen. In T. A. Davies et al. (eds.): Glaciated continental margins-an atlas of acoustic images. Pp. 175-178. London: Chapman and Hall.

Wiktor, J. 1999: Early spring microplankton development under fast ice covered fjords of Svalbard, Arctic. Oceanologia 41, 51-72.

Winther, J.-G. 1993: Landsat TM derived and in situ summer reflectance of glaciers in Svalbard. Polar Res. 12, 37-55.

Winther, J. -G., Gerland, S., Ørbæk, J. B., Ivanov, B., Blanco, A. \& Boike, J. 1999: Spectral reflectance of melting snow in a high Arctic watershed on Svalbard: some implications for optical satellite remote sensing studies. Hydrol. Process. 13, 2033-2049.

Winther, J.-G., Gerland, S., Ørbæk, J. B., Ivanov, B., Zachek, A. S. \& Bezgreshnov, A. M. 2001: Effects on spectral reflectance from snow ageing. Mem. Natl. Inst. Polar Res., Spec. Issue 54, 193-201. Tokyo: National Institute of Polar Research.

Winther, J.-G., Godtliebsen, F., Gerland, S. \& Isachsen, P. E. 2002: Surface albedo in Ny-Ålesund, Svalbard: variability and trends during 1981-97. Glob. Planet. Change, 127-139.

Zajaczkowski, M. 1997: The methodology of measuring sedimentation in glaciated fjords. In: Wyprawy geograficzne na Spitsbergen. (Geographical expedition to Spitsbergen.) Pp. 122-221. Lublin, Poland: University Maria CurieSklodowska.

Zajaczkowski, M. \& Legezynska J. 2001: Estimation of zooplankton mortality caused by an Arctic glacier outflow. Oceanologia 43, 341-351. 